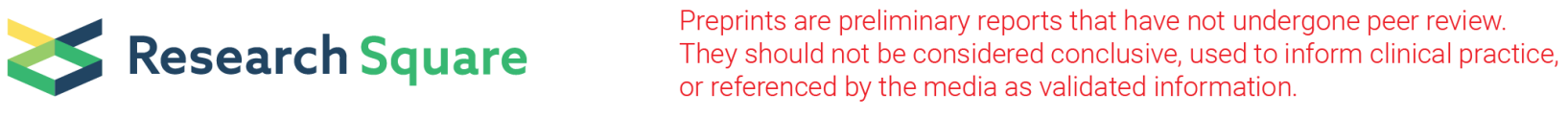

\title{
Evaluation of geotechnical properties, petrographic characteristics and ultrasonic wave velocity of weak sandstones
}

Waleed Abdelmoghny Metwaly Ogila ( $\nabla$ walid_ogala@sci.asu.edu.eg )

Ain Shams University Faculty of Science https://orcid.org/0000-0002-9458-4670

Mohamed H. Abdel Aal

Ain Shams University Faculty of Education

Sahar M. Abd El Bakey

Ain Shams University Faculty of Education

\section{Research Article}

Keywords: weak sandstones, mechanical properties, compressibility of weak rock, wave velocity, petrography, simple and multiple regression analyses

Posted Date: April 15th, 2021

DOI: https://doi.org/10.21203/rs.3.rs-379752/v1

License: (c) (i) This work is licensed under a Creative Commons Attribution 4.0 International License. Read Full License 


\section{Abstract}

Several new settlements have been constructed in the desert areas of Egypt. These new settlements are composed of many new types of problematic formations that creating many geological and engineering challenges. One of the most problematic formations is weak sandstones that are characterized by low mechanical strength and bearing capacity as well as high deformability and fracturing. The physico-mechanical characteristics of these sandstones are the most crucial parameters in design and stability evaluation of any surface and underground engineering structures. The determination of these parameters is complicated, difficult and time consuming as well as is required a great accuracy in sample preparation and testing procedure, and is considered as expensive testing. The objective of this study is analyzing the shallow marine weak sandstones to determine the best and significant correlations of petrographic characteristics and physical engineering index properties that may be useful for estimating unconfined compressive strength (UCS), uniaxial pore volume compressibility $\left(m_{v}\right)$, compressional P-wave velocity $\left(V_{p}\right)$ and dynamic constrained modulus $\left(E_{s}\right)$. As well as predicting the UCS and $m_{v}$ from compressional P-wave velocity test and estimating the petrographic parameters from the physical engineering index parameters. The present study revealed that the studied samples are high to very high porous sandstones with very low to moderate density, and classified as extremely weak to weak rocks with very high deformability and very low wave velocity. In this study, the physical properties form non-significant linear relations with $U C S, V_{p}$, and $E_{s}$ as well as there are moderately strong to strong correlations between P-wave velocity, constrained modulus, unconfined compressive strength and compressibility characteristics. Based on the regression analysis, the dolomite cement and matrix contents, quartz and rock fragments contents, packing density and proximity, sorting, roundness, mean grain size, and grain to cement contact exhibited weak to strong statistical correlations with mechanical properties of the studied sandstones. These relationships revealed that due to the mineralogical, textural, and microstructure variations of the studied recycle origin sandstones, the non-significant to significant relations are resulted. In this study, the backward multiple regression was applied to predict the UCS, $m_{v}, v_{p}$ and $E_{s}$ of the studied sandstones by selecting some physical and petrographic characteristics which exhibit statistically significant correlations with them. The results of this study were presented in the form of predictive models and equations.

\section{Introduction}

Several new settlements have been constructed outside of Nile delta region through the desert areas east of Greater Cairo, Egypt. These new settlements are mainly composed of many new types of problematic formations that creating many geological and engineering challenges to understand, evaluate and treatment of these new problematic formations. One of the most problematic formations is extremely weak to weak sandstones whereas these sandstones are characterized by low mechanical strength and bearing capacity as well as high deformability and fracturing. The physico-mechanical characteristics of these sandstones are the most crucial parameters in design and stability evaluation of any surface and underground engineering structures as dams, tunnels, roads and highways, and cut slopes.

Olivera (1993) revealed that the weak rocks are characterized by four relevant properties which are poorly cementation particles, high void percentage between particles, weathering and tectonic disturbance, and immature mineral composition. According to ISRM (1981) the extremely weak and weak rocks have compressive strength ranging between $0.25 \mathrm{MPa}$ and 25.0 MPa, and according to Egyptian code (2007) the extremely weak and medium weak rocks have compressive strength less than $12.5 \mathrm{MPa}$. The poor cementation bonding, as well as present of potential percentages of cavities and fractures or discontinuities are the main factors for low strength values of these weak rocks (Nassif, 2003). Therefore, the undisturbed sampling of these weak rocks for laboratory testing such as compressive strength and deformation tests is considerably very difficult.

The laboratory testing of these properties is complicated, difficult and time consuming as well as is required a great accuracy in sample preparation and testing procedure, and is considered as expensive testing. For these reasons, the prediction of 
these expensive and time-consuming mechanical parameters of weak sandstones from simple, indirect, non-destructive, cheap and reliable methods by using statistical empirical equations is mostly applied for preliminary studies.

Due to the different cementation and diagenesis process during sedimentation and burial history of sandstones, the mechanical properties as compressive strength, young's modulus, poisson's ratio and pore volume compressibility are widely varied. These variations in mechanical characteristics have been attributed to the variations in petrographic characteristics of the different sandstones (Bell, 1978; and Fahy and Guccione, 1979). The mechanical characteristics of a rock are affected by mineralogical composition, texture, microstructure, moisture content, porosity, density, temperature-pressure conditions and deformation rate (Bell, 1983). Meng et al. (2006) suggested that the mechanical properties of the weak sandstone rocks are mostly influenced not only by external factors as surrounding geological and stress/strain conditions but also are strongly influenced by the environment of deposition as well as burial history and diagenesis process including mineral composition, microstructures and textures.

Many researchers investigated the correlation of petrographic characteristics and ultrasonic wave velocity with mechanical parameters of sandstone rocks and had come out with some interesting viewpoints (Bell, 1978; Vutukuri et al., 1978; Fahy and Guccione, 1979; Doberenier and De Freitas, 1986; Shakoor and Bonelli, 1991; Ulusay et al., 1994; Bell and Lindsay, 1999; Chen and Ye Hu, 2001; Jeng et al., 2004; Singh et al., 2005; Meng et al., 2006; Sharm and Singh, 2008; Moradian and Behnia, 2009; Sarkar et al., 2012; Heidari et al., 2013; Ktena and Sabatakakis, 2013; Nefeslioglu, 2013; Khandelwal, 2013; Kurtuluş et al., 2016; Azimian and Ajalloeian, 2015; Abu Seif, 2016; Yar et al., 2017; and Othman and Ali, 2017).

Bell (1978) studied the impact of petrographic parameters on mechanical properties of sandstones and suggested that the strength and elastic characteristics of sandstone increase with increase packing density (PD), in addition to there is no significant relations of quartz content (Qz\%) and other mineralogical composition of sandstones with their strength. On the other hand, Howarth and Rowlands (1986) revealed that the microstructure and texture parameters including packing density (PD) had moderate correlations with several mechanical properties of sandstones.

Fahy and Guccione (1979) demonstrated that the mean and median grain sizes, percent of quartz grains and sphericity of calcareous sandstones have strong negative correlations with unconfined compressive strength (UCS), while the total percent of carbonate content and percent of straight grain contacts have strong positive relations with UCS. Doberenier and De Freitas (1986) concluded that the weak sandstones mostly have low packing density and the increasing of some types of grain contacts and decreasing of grain size were mostly related to increase the mechanical strength of the studied weak sandstones.

The sandstones with high density, low absorption and pore volume, and high percentage of suture contacts mostly have high values of compressive and tensile strengths and young's modulus, in addition to low values of poisson's ratio. On the other hand, the sandstones with abundance of grain to void contacts, grain to matrix contacts and straight contacts have low values of mechanical strength parameters (Shakoor and Bonelli, 1991). They also revealed that the degree of sorting $\left(\mathrm{S}_{\mathrm{r}}\right)$, mean grain size (mgs), packing density (PD), packing proximity (PP) and sphericity $\left(\mathrm{S}_{\mathrm{ph}}\right)$ had moderately significant to nonsignificant correlations with mechanical characteristics of studied sandstones.

Ulusay et al. (1994) founded that the textural characteristics of sandstones are more important than their mineralogical composition in predicting the engineering parameters. They suggested that the sandstones with high percent of sutured contacts and angular grains have high strength as well as the sandstones with abundance of grain to grain contacts and high values of packing proximity exhibited high young's modulus and low poisson's ratio. They founded that the PD, PP, and roundness have moderately significant to significant correlations, while the $\mathrm{S}_{\mathrm{ph}}, \mathrm{S}_{\mathrm{r}}$, mgs, contact types, Qz\%, rock fragments (RF\%), matrix\%, number of contacts and other types of grain to grain contacts as point, straight and concave-convex contacts have non-significant to moderately significant correlations with mechanical properties of studied sandstones.

Bell and Lindsay (1999) studied the fine to medium grained arkosic sandstones and demonstrated that few petrographic parameters have a notable influence on the mechanical properties whereas the increasing of clay content leads to decreasing 
the UCS while the increasing of Qz\% tends to enhance it. They also reported that the cement\%, total contact types, PP, PD, S and median size have no impact on UCS while the effective porosity $(\phi)$ has high significant inversely relationship with UCS, Brazilian strength and point load index of studied sandstones. On the contrary, Chen and Ye Hu (2001) revealed that the increasing of Qz\% and water content, and decreasing the porosity mostly accompanied with decreasing of UCS, wave velocity and slake durability of the studied weak sandstones.

Jeng et al. (2004) studied the tunnel squeezing occurred during tunneling through Tertiary sandstones in northern Taiwan and they demonstrated that the geotechnical properties of sandstones differ from one to another due to wetting softening phenomena. They suggested that the grain area ratio and porosity are considered the key parameters to predict the dry UCS and strength reduction due to wetting whereas the high porosity and low grain area ratio resulted in significant wetting softening. Meng et al. (2006) examined the impact of depositional environment of clastic rocks on their mechanical properties and they revealed that the detrital and quartz contents have greatly effects on the mechanical parameters, where when the detrital and quartz contents exceeded $50.0 \%$ and $40.0 \%$, respectively, the UCS and elastic modulus had dramatic increasing while the decreasing of grain size is accompanied with increasing these mechanical parameters until the peak value at grain size $0.177 \mathrm{~mm}$ after which these parameters reduced dramatically as grain size decrease due to grain diameter softening effect.

Heidari et al. (2013) studied the relationships between petrographic characteristics and engineering properties of sandstones located in west Iran by using simple linear regression and stepwise multiple linear regression analyses. They founded that the PD, $\phi$, PP and percentage of long contacts appeared the significant relations with engineering properties. They also suggested that the textural criteria of sandstones are more important than mineralogical composition whereas the mineralogical composition has no relationships with density, porosity, strength and tangent modulus.

Ktena and Sabatakakis (2013) suggested that the increasing of Qz\%, PD and grain area ratio, and decreasing matrix\% were resulting in increase in strength parameters of studied sandstones; on the contrast Abu Seif (2016) demonstrated that the $\phi$ and density $(\mathbb{P})$ had been considered as the key parameters influencing the ultrasonic wave velocity, UCS, and point load index. Yar et al. (2017) suggested that the modal composition, sorting and grain size appear to be controlling the strength the sandstones.

Ultrasonic compressional velocity, $\mathrm{V}_{\mathrm{p}}$, is widely used in prediction of mechanical and dynamic characteristics of intact rocks, where this technique is simple, non-destructive and easy to apply in both site and laboratory conditions as compared to the static properties of these intact rocks.

Vutukuri et al. (1978) and Sharm and Singh (2008) suggested that the ultrasonic wave velocity of rock mass is mostly impacted by several factors include modal composition, texture, density, porosity, pore water, weathering and alteration, bedding plane, joint properties and confining pressure. The ultrasonic wave velocity also depends on the degree of compaction of earth materials whereas the well compacted rock has a high velocity as the all grains are mostly in good contact while the poorly compacted rock is mostly having a high percentage of voids that dampen the passage of waves through the rock and reducing the wave velocity (Singh et al., 2005). Therefore, the wave velocity of intact rocks depends on density, chemical composition and hardness of rock materials.

Moradian and Behnia (2009) and Nefeslioglu (2013) predicted the UCS and static elastic modulus of various intact sedimentary rocks from non-destructive ultrasonic technique and proposed some practical simple and accurate equations that can be used in practice for engineering purposes with acceptable accuracy. On the same manner, Sarkar et al. (2012) investigated the impact of compressional wave velocity on the index geomechanical parameters of thirteen different igneous, sedimentary and metamorphic rocks and they showed that the compressive wave velocity has strong positive correlations with density, slake durability index, and UCS with correlation coefficient (R) greater than +0.951 .

Khandelwal (2013) established empirical relations of P-wave velocity with UCS, young's modulus, tensile strength, punch shear, slake durability index, density, poisson's ratio, impact strength index and Schmidt hammer rebound number for 
different rock types and founded that the P-wave velocity has very strong linear correlations with different physicomechanical properties with very high correlation coefficient values "R >+0.91". Also, Azimian and Ajalloeian (2015) developed empirical relations between P-wave velocity and physico-mechanical parameters of marly rocks; the results of this study indicated that there are strong significant correlations of P-wave velocity with density, weight percentage of water absorption, porosity, slake durability index, UCS and modulus of elasticity with correlation coefficient values above 0.94 .

Kurtuluş et al. (2015) and Abu Seif (2016) investigated the relationships of wave velocity with physico-mechanical parameters of different sedimentary intact rocks and developed new strong correlations between them with correlation coefficient values more than 0.70. On the other hand, Othman and Ali (2017) studied the correlations of some dynamic properties of very weak to medium strong sandstones as compressional and shear wave velocities, modulus of rigidity, young's and bulk moduli, and poisson's ratio with their physical and mechanical properties. They founded that; the dynamic parameters have strong to moderately significant correlations with static parameters with correlation coefficient values lager that 0.5 .

The land subsidence problems in sandstone rock mass are created/introduced due to dewatering processes through high porous very weak to weak sandstone rocks during mining and tunneling operations, aquifer water extraction and dewatering system of soaked foundation sandstone layers under infrastructures of dams and buildings. This land subsidence is caused mostly by withdrawal of fluid and resulting in collapse of underground openings (Nikraz et al., 1995 and 2012). Deformations of these weakened sandstones due to water pressure decline are either elastic or non-elastic deformations, the elastic deformations are mostly negligible and being only of importance in respect to the variation of water flow rate. On the other hand, the non-elastic deformations are mostly due to compaction or migration of rock components that are depend on characteristics of the soaked rock and the extent of dewatering. The compaction mostly causes regional subsidence, while the migration of rock components causes local displacement (Nikraz et al., 1995 and 2012).

One of the most measuring land subsidence techniques is predicting the porous rock substance or formation compaction due to fluid withdrawal from laboratory compressibility data (Teeuw, 1971). In this technique the vertical compaction of porous rock is derived from hydrostatic one-dimensional compaction data. For this one-dimensional vertical compaction, Geertsma (1966 and 1973) suggested that the vertical deformation of a prism of the porous rock can be expressed by the following equation:

$\Delta \mathrm{h}=\mathrm{C}_{\mathrm{m}}{ }^{*} \mathrm{~h}^{\star} \mathrm{P}$

Where

$\mathrm{C}_{\mathrm{m}}$ : is the one-dimensional compaction coefficient, $\Delta \mathrm{h}$ : is the change in the prism height, $\mathrm{h}$ : is the prism height, and $\Delta \mathrm{P}$ : is the change or reduction in pore fluid pressure.

The vertical deformation equation was adapted by Teeuw (1971) with respect of poisson's ratio of the porous rocks as the following:

$\varepsilon_{\mathrm{z}}=\mathrm{C}_{\mathrm{m}} * \Delta \mathrm{P}=(1 / 3(1+\mathbb{Q}) /(1-\nabla)) * \mathrm{e}$

Where

$\varepsilon_{\mathrm{z}}$ : is the uniaxial compaction "relative change in height", 邓: is poisson's ratio, e: is hydrostatic volumetric compaction "relative change in bulk volume".

Nikraz et al. (1995 and 2012) evaluated the compaction associated with dewatering of weak sandstone rocks as an aid to surface subsidence prediction by using triaxial test technique which allows the strata compacted under triaxial loading with zero lateral strain. They performed a series of triaxial compaction tests to determine the compressibility and in situ behavior of the studied weak rocks. They founded that the rock degradation was observed and quantified by the weight of particles 
washed out from specimen, as well as the saturated tensile strength was reduced with about $12.0 \%$ and fracturing of the studied sandstones was observed during simulated dewatering. They also suggested that the majority of volume changes occurred within the first eight hours and $82.0-86.0 \%$ of specimen volume change occurred within the first twenty minutes during the first loading cycle.

The objective of this study is analyzing the shallow marine weak sandstones collected from new settlements north of CairoIsmailia road northeast of Grater Cairo, Egypt, to determine the best and significant correlations of petrographic characteristics and physical engineering index properties of the studied sandstones that may be useful for estimating unconfined compressive strength (UCS), uniaxial pore volume compressibility $\left(m_{v}\right)$, compressional P-wave velocity $\left(V_{p}\right)$ and dynamic constrained modulus $\left(E_{S}\right)$. As well as predicting the UCS and $m_{v}$ from non-destructive, simple, cheap compressional P-wave velocity test and estimating the petrographic parameters of the studied sandstones from the physical engineering index parameters. In this study, the data were subjected to linear and non-linear regression analyses to obtain the best curve fits with highest correlation coefficient (R). Finally, the predictive empirical models, based on multiple variables statistical regression backward iteration method by using IBM SPSS statistics computer's software package (V.25) which has capability to extract the influence of key parameters one by one, were developed employing the most key parameters to estimate the mechanical, compressibility and ultrasonic properties of studied weak sandstones.

\section{Material And Experimental Setup}

Twenty-one different shallow marine pale to dark yellowish orange sandstone samples were collected from the foundation bedrocks of some buildings and exposed outcrops through new constructed settlements north of Cairo-Ismailia road, northeast of Greater Cairo, Egypt. Stratigraphically, the area north Cairo-Ismailia road is made up of Miocene to Quaternary formations. The Miocene sedimentary sequence is divided by many researchers (Shukri, 1953; Shukri and Akmal, 1953; ElBelasy, 1968; Said, 1990; Swedan 1991; and Abu-Zeid et al., 2004) into marine Miocene rocks "lower to middle Miocene age" and non-marine Miocene sand "upper Miocene age". The lower-middle marine Miocene comprises two subunits, the lower Miocene subunit is made up of sandstone at the base and algal dolomitic limestone at the top and interbedded with silty clay. The sandstone rocks are weak to moderately hard and fragmented in some places, fine to very coarse grained, poorly sorted, calcareous to highly calcareous and argillaceous in some places, fossiliferous (algae, molluscs, and echinoids) and occasionally cross bedded (Abu-Zeid et al., 2004). The dolomitic limestone is mostly sandy and fossiliferous, hard and porous, as well as the top most part of this layer composed of thin carbonate conglomeratic layer. The upper Miocene subunit is composed of hard, porous, fractured and fossiliferous dolomitic limestone to dolostone interbedded with claystone layers in some places (Abu-Zeid et al., 2004). The non-marine upper Miocene unit is made up of white to grey coarse-grained quartz sand intercalated by gravel beds with abundance of silicified wood (Swedan, 1991).

The Miocene sediments exhibit great facies variation and have large number of unconformities reflecting the nature of tectonically formed basins whereas these basins form a neritic marginal zone which was intermittently covered by the sea, as well as the sediments are thin and are mostly made up of shallow deposits (Said, 1990).

Abu-Zeid et al. (2004) studied the lower Miocene sandstone rocks in El-Obour City, north of Cairo-Ismailia road and revealed that these rocks are classified as carbonate sandstone to calcareous muddy sandstone, mostly poorly sorted with fluvial to shallow marine origin. They also suggested that the studied rocks were diagenetically affected by compaction cementation, dolomitization, replacement and dissolutions. The dolomitization of calcite cement and fossils resulted in extensive corrosion of quartz grains at their borders and dissolution processes led to produce the vuggy, moldic and fracture porosity "intraparticles and interparticles porosity".

The Quaternary sediments are represented by wadi alluvial and aeolian sand dune deposits.

Structurally, the area is affected by faults, folds and unconformities. The faults have two main sets, the first set is east-west normal faults forms step fault blocks as well as horst and graben blocks while the second set is northwest-southeast normal 
faults. The folds are nearly symmetrical and mostly have dominant east-northeast to northeast orientation, where the largescale folds are mostly doubly plunging while the small-scale folds are of the drag type associated with diagonal faults.

Free visible defects twenty-one sandstone blocks with visual difference in their texture were collected and cored in laboratory to obtain $2.5 \mathrm{~cm}$ diameter cores with a length to diameter ratio (L/D) of 2.0. The two ends of core cylindrical specimens were lapped parallel and polished to measure unconfined compressive strength (UCS) and ultrasonic compressive wave velocity $\left(\mathrm{V}_{\mathrm{p}}\right)$.

The physical index parameters as dry density $\left(\mathbb{P}_{d}\right)$ and specific gravity $\left(G_{s}\right)$ were determined in accordance with ASTM standards where these index physical properties have been shown to be closely related to mechanical and wave velocity through the studied sandstones. The permeability $(k)$ and porosity $(\phi)$ of the studied sandstones were measured during determination of pore volume compressibility $\left(m_{v}\right)$ for the studied sandstone core samples according to the test procedure that described by Teeuw (1971) to measure the rock compaction from triaxial test with zero lateral deformation. This test procedure was carried out in Egyptian Petroleum Research Institute (EPRI).

The studied cored sandstone samples with polished two ends are subjected to ultrasonic pulse velocity measurements by using PUNDIT PLUS device that generates suitable mechanical pulses and accurately measures the time of their transmission "with a precision of 0.1 us" through the tested samples according to ASTM procedure (D 2845, 2003). The samples were tested at room temperature and in dry condition with suitable signal frequency " $50 \mathrm{kHz}$ " to reduce scattering and poorly defined first arrivals according to ISRM (2007), as well as the jell was used as an ultrasonic couplant to improve surface contact between the transducers and tested sample interfaces that resulting in improvement of measured signals (Starzec, 1999). The mechanical pulses generated by the instrument are travelled from transmitter piezo-electric transducer at one end and received at another end of core specimen by receiver piezo-electric transducer. The wave velocity was calculated from the measured travel time and the distance between the transmitter and receiver. The ultrasonic compressive P-wave velocity, $\mathrm{V}_{\mathrm{p}}$, was measured three times for each sandstone sample and the average value is considered as the representative value. The constrained modulus $\left(\mathrm{E}_{\mathrm{s}}\right)$ or P-wave modulus was calculating using the following equation according to Fratta and Santamarina (1996):

$E_{s}=\mathbb{P}_{d} *\left(V_{p}\right)$

The sandstone core samples that used in measuring the P-wave velocity were then subjected to the uniaxial compressive strength (UCS) tests in laboratory. The UCS test was carried out on the studied sandstone samples by using universal testing machine according to ISRM suggested technique (Brown, 1981), and Egyptian Code (2007). UCS is normally determined by statically loading a cylinder of rock to failure, the load being applied across the upper and lower faces of the rock sample. The results obtained are in part a function of the length breadth ratio of the sample. The measured value of uniaxial compressive strength is determined as follows:

\section{UCS $=$ P/A}

Where UCS: measured uniaxial compressive strength; P: maximum applied load; A: cross section area.

One thin section was made for each of the twenty-one sandstone core samples subjected to UCS test. These thin sections were examined by using a petrographic optical polarizing microscope to investigate their petrographic characteristics including mineralogical composition, mean grain size (mgs), packing density (PD) and packing proximity (PP), degree of sorting $\left(S_{r}\right)$, grain shape including sphericity $\left(S_{p h}\right)$ and degree of roundness $\left(R_{d}\right)$, alteration degree, extinction, and degree of grain interlocking including types of grain to grain contacts and number of contacts per grain, in addition to textural maturity.

According to the described method by Hutchinson (1974), the mean grain size of each sample was measured by an eye-piece micrometer. The average of two perpendicular dimensions passing through the center of each grain provides the grain size, the average of grain size for one-hundred randomly selected grains per thin section is considered the mean grain size for the 
studied sample. The degree of grain sorting for each studied sample thin section was measured based on the visual classification chart developed by Compton (1962), ten fields of view per each thin section were evaluated to measure this petrographic parameter where each field of view contains 50 to 100 grains. The degree of sorting for each studied sample was classified with numerical value according to Folk (1974) from 0.0 to greater than 4.0 "very well sorted to extremely poorly sorted, respectively".

The degree of roundness of clastic grains was expressed by the sharpness of their edges and corners that measured according to the comparison chart developed by Powers (1953), with rho roundness scale ranging from 0.0 for very angular grains to 6.0 for well rounded grains according to Folk (1974). On the other hand, the sphericity of clastic grains showing the degree of which the shape of grain approaches as a sphere. The sphericity of grains was measured in thin section according to Folk's classification system (Folk, 1974) whereas the sphericity is the ratio of short axis to the long axis. The grain shape parameters for each thin section were quantified for 50 randomly selected grains according to the recommended method by Pettijohn et al. (1987).

The grain packing arrangements "packing density" and spacing between grains "packing proximity" as well as the degree of grain interlocking including the percentage of types of grain to grain contacts, such as point, concavo-convex, straight and sutured contacts, and the number of contacts per grain " such as percentage of grain to grain, grain to voids, grain to cement, and grain to matrix" were determined along ten traverses per thin section according to the methods proposed by Kahn (1956) and Blatt (1982) as shown in figure (1).

The modal composition analysis was made on 150 randomly selected points according to point-count method mentioned by Hutchinson (1974) to determine the mineral composition such as contents of quartz, feldspars, rock fragments, iron oxides, dolomite and calcite cement materials, and silt and clay matrix. Finally, textural maturity of the studied sandstone samples was determined according to concept assumed by Folk (1974).

\section{Results And Discussion Of Simple Regression Models Physical and mechanical index properties of studied sandstones}

Table (1) provides the summary of the physical and mechanical parameters of the studied sandstone rock samples. The dry density $\left(\mathbb{P}_{d}\right)$ of the studied samples is determined according to ASTM procedure $(D 7263-09,2018)$ and is ranging between

$1.41 \mathrm{gm} / \mathrm{cm}^{3}$ and $2.43 \mathrm{gm} / \mathrm{cm}^{3}$ with an average of $2.08 \mathrm{gm} / \mathrm{cm}^{3}$. These density values indicated that the studied sandstones ranging from very low density to moderate density rocks according to International Association of Engineering Geology (IAEG, 1979). These low-density values for the studied sandstone are mostly influenced by the porosity percentage in addition to the cement and matrix materials occupying these pore spaces, packing density and diagenetic processes (Tucker, 2003). The specific gravity $\left(G_{s}\right)$ of the studied samples is measured according to ASTM $\left(D\right.$ 854, 2003), the $G_{s}$ values of the studied samples are ranging from 2.65 to 2.81 with average value of about 2.71 .

The total porosity $(\phi)$ and permeability $(k)$ are calculated during measuring the pore volume compressibility $\left(m_{v}\right)$ for the studied sandstone samples according to Teeuw (1971). The porosity and permeability of the studied samples are ranging from $16.1-33.2 \%$ with an average of about $22.08 \%$, and from 1.0 millidarcy to 2467.0 millidarcy with average of about 404.96 millidarcy (md), respectively. According to IAEG (1979) the studied sandstone samples are classified as high to very high porous sandstone.

\section{Table (1)}

The physical and mechanical index properties of the studied sandstones. 


\begin{tabular}{|c|c|c|c|c|c|c|c|c|}
\hline S. No. & $\begin{array}{l}\text { Density } \\
\left(\mathrm{gm} / \mathrm{cm}^{3}\right)\end{array}$ & $\begin{array}{l}\text { Specific } \\
\text { gravity }\end{array}$ & $\begin{array}{l}\text { Total } \\
\text { porosity } \\
(\%)\end{array}$ & $\begin{array}{l}\text { Permeability } \\
\text { (md) }\end{array}$ & $\begin{array}{l}\text { Unconfined } \\
\text { compressive } \\
\text { strength } \\
\text { (MPa) }\end{array}$ & $\begin{array}{l}\text { P-wave } \\
\text { velocity } \\
\text { (m/s) }\end{array}$ & $\begin{array}{l}\text { Constrained } \\
\text { modulus } \\
\text { (GPa) }\end{array}$ & $\begin{array}{l}\text { Pore volume } \\
\text { compressibility } \\
\mathrm{m}_{\mathrm{v}}\left(\mathrm{Psi}^{-1}\right)\end{array}$ \\
\hline 1 & 1.82 & 2.67 & 24.50 & 46.00 & 0.34 & 379.82 & 0.26 & 0.0000405 \\
\hline 2 & 2.03 & 2.67 & 23.60 & 71.00 & 1.38 & 309.20 & 0.19 & 0.0000329 \\
\hline 3 & 1.99 & 2.68 & 24.00 & 33.00 & 1.47 & 332.50 & 0.22 & 0.0000345 \\
\hline 4 & 2.43 & 2.72 & 22.80 & 4.80 & 1.03 & 497.31 & 0.60 & 0.0000137 \\
\hline 5 & 2.11 & 2.73 & 23.20 & 1.00 & 2.47 & 431.48 & 0.39 & 0.0000193 \\
\hline 6 & 2.09 & 2.72 & 23.60 & 4.00 & 2.83 & 416.17 & 0.36 & 0.0000270 \\
\hline 7 & 1.81 & 2.78 & 33.20 & 1073.00 & 0.34 & 482.01 & 0.42 & 0.0000565 \\
\hline 8 & 1.93 & 2.78 & 30.50 & 2467.00 & 2.93 & 577.69 & 0.64 & 0.0000152 \\
\hline 9 & 1.95 & 2.81 & 30.60 & 490.00 & 3.25 & 703.70 & 0.96 & 0.0000105 \\
\hline 10 & 2.30 & 2.66 & 18.70 & 1744.00 & 1.72 & 586.99 & 0.79 & 0.0000350 \\
\hline 11 & 1.41 & 2.65 & 25.70 & 1761.00 & 0.50 & 269.67 & 0.10 & 0.0000286 \\
\hline 12 & 1.93 & 2.67 & 25.50 & 2.90 & 0.50 & 213.97 & 0.09 & 0.0000327 \\
\hline 13 & 2.40 & 2.71 & 18.80 & 25.00 & 2.76 & 456.24 & 0.50 & 0.0000496 \\
\hline 14 & 2.23 & 2.69 & 17.10 & 12.00 & 4.13 & 526.41 & 0.62 & 0.0000271 \\
\hline 15 & 2.22 & 2.71 & 17.70 & 193.00 & 4.38 & 607.57 & 0.82 & 0.0000183 \\
\hline 16 & 2.11 & 2.69 & 18.35 & 154.50 & 2.39 & 470.45 & 0.47 & 0.0000488 \\
\hline 17 & 2.21 & 2.69 & 18.00 & 119.00 & 2.77 & 633.65 & 0.89 & 0.0000284 \\
\hline 18 & 2.18 & 2.68 & 18.70 & 190.00 & 2.01 & 361.66 & 0.28 & 0.0000691 \\
\hline 19 & 1.99 & 2.72 & 16.10 & 21.00 & 6.89 & 672.88 & 0.90 & 0.0000172 \\
\hline 20 & 2.29 & 2.73 & 16.40 & 6.00 & 4.91 & 670.44 & 1.03 & 0.0000214 \\
\hline 21 & 2.28 & 2.73 & 16.70 & 86.00 & 3.19 & 506.71 & 0.58 & 0.0000382 \\
\hline Average & 2.08 & 2.71 & 22.08 & 404.96 & 2.48 & 481.26 & 0.53 & 0.00003165 \\
\hline
\end{tabular}

The dry density of the studied sandstones shows indirect linear relationships with total porosity and permeability with correlation coefficient values $\mathrm{R}=-0.622$ and -0.433 , respectively (Tab., 2 ).

The unconfined compressive strength values of the studied sandstones (Table 1) show that the UCS varies from 0.34 MPa to 6.89 MPa with an average of about 2.48 MPa. According to IAEG (1979), ISRM (1981) and Egyptian Code (2007) classifications, the studied sandstones are classified as extremely weak to weak rocks. The values of ultrasonic P-wave velocity $\left(V_{p}\right)$ and constrained modulus $\left(E_{s}\right)$ of the studied sandstones are varied from $213.97 \mathrm{~m} / \mathrm{s}$ to $703.7 \mathrm{~m} / \mathrm{s}$ with an average of $481.26 \mathrm{~m} / \mathrm{s}$; and from $0.09 \mathrm{GPa}$ to $1.03 \mathrm{GPa}$ with an average of $0.53 \mathrm{GPa}$, respectively (Table 1 ). According to IAEG (1979) classification, the studied sandstones are considered as very low velocity with very high deformability.

The physical properties of the studied rocks form non-significant linear relations with UCS, $V_{p}$, and $E_{s}$ with correlation coefficient values ranging from \pm 0.25 to \pm 0.58 , (Table 2), where these parameters increase with an increase of $G_{s}$ and $\mathbb{P}_{d}$ and with a decrease of $\phi$ that agree with many researchers as Escartin et al. (2001), Sabatakakis et al. (2002), Yasar and 
Erdogan (2004), Christensen (2004), Diamantis et al. (2009), Yagiz (2011), Altindag (2012), Azimian and Ajalloeian (2015), and Abu Seif (2016).

To improve these relationships, the non-linear exponential, logarithmic, polynomial and power regression models were executed and the approximation equations with highest correlation coefficients were determined for each regression as shown in figure (2).

Uniaxial pore volume compressibility $\left(\mathrm{m}_{\mathrm{v}}\right)$ values for the studied sandstones are ranging from $10.54{ }^{\star} 10^{-6} \mathrm{Psi}^{-1}$ to $69.12^{\star} 10^{-}$ ${ }^{6} \mathrm{Psi}^{-1}$ with an average value of about $31.65^{\star} 10^{-6} \mathrm{Psi}^{-1}$ (Table 1). Newman (1973) divided the sandstone rocks according to their compressibility by using a qualitative rock-typing system into consolidated or hard rocks, friable rocks and unconsolidated rocks. The consolidated or hard rocks are characterized by their thin edges couldn't be broken off by hand with $\mathrm{m}_{\mathrm{v}}$ values ranging from $1.5^{*} 10^{-6}$ to $20^{*} 10^{-6} \mathrm{Psi}^{-1}$, the friable rocks are characterized by their thin edges could be broken off by hand with $\mathrm{m}_{\mathrm{v}}$ values ranging from $2.5^{\star} 10^{-6}$ to $45^{\star} 10^{-6} \mathrm{Psi}^{-1}$, and the unconsolidated rocks are fall apart under their own weight with $\mathrm{m}_{\mathrm{v}}$ values ranging from $5.5^{\star} 10^{-6}$ to $85^{\star} 10^{-6} \mathrm{Psi}^{-1}$. Based on this classification, seventeen studied sandstone samples are considered as friable sandstone rocks and other four studied samples are classified as unconsolidated sandstone rocks which indicated that these studied sandstones are considered as high deformability rocks. The $\mathrm{m}_{\mathrm{v}}$ forms weak linear inverse correlations with physical parameters of studied sandstones with correlation coefficient values lower than -0.35 (Table 2).

Plotting the relations of UCS with $\mathrm{V}_{\mathrm{p}}$ and $\mathrm{E}_{\mathrm{s}}$ parameters of the studied sandstones revealed that, there are strong positive simple linear relations with correlation coefficient values $R=+0.72$ and +0.73 , respectively (Table 2, and Fig. 3 ) as the following equations.

UCS $=0.0086\left(V_{p}\right)-1.6759 R=+0.72$

$E_{S}=0.127(U C S)+0.2148 R=+0.73$

Where

USC: unconfined compressive strength (MPa), $\mathrm{V}_{\mathrm{p}}$ : P-wave velocity $(\mathrm{m} / \mathrm{s})$, and $\mathrm{E}_{\mathrm{s}}$ : constrained modulus $(\mathrm{GPa})$.

These relations are expected because these parameters are depended on the same factors as mineralogical composition, texture and structure, density, porosity, alteration and weathering degree parameters as well as they are indicators for the elasticity of the studied rocks. These relations agree with Abdel-Aaal et al. (2004), Yagiz (2011), Khandelwal (2013), Azimian et al. (2014), Azimian and Ajalloeian (2015), and Abu Seif (2016).

The pore volume compressibility has inverse moderate to strong relations with $U C S, V_{p}$, and $E_{s}$ with correlation coefficient values ranging from -0.43 to -0.52 (Table 2 , and Fig. 3 ). So that, the compressibility of extremely weak to weak shallow marine sandstones can be predicted from the other simple and cheap experimental tests as the following equations.

$m_{v}=7 * 10^{-5 *} e^{-0.002(V p)} R=-0.52$

$\mathrm{m}_{\mathrm{v}}=4^{*} 10^{-5 *} \mathrm{e}^{-0.125(\text { UCS) }} \mathrm{R}=-0.43$

$m_{v}=5^{\star} 10^{-5 *} e^{-1.294(E s)} R=-0.52$

\section{Table (2)}

Correlation Coefficient matrix of index physico-mechanical, ultrasonic wave velocity, and petrographic parameters of studied sandstones.

Page $10 / 32$ 


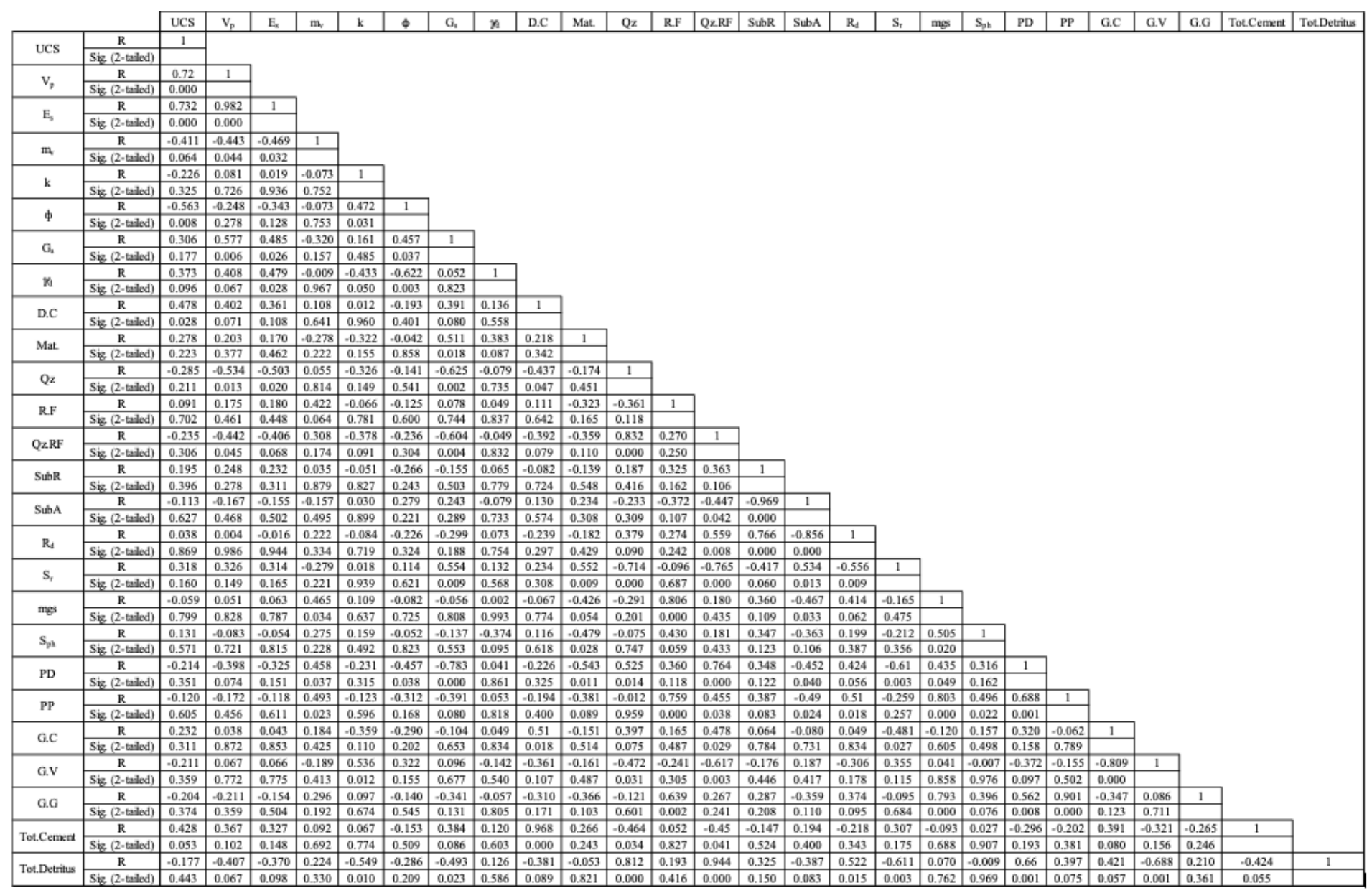

UCS: unconfined compressive strength, $\mathrm{V}_{\mathrm{p}}$ : P-wave velocity, $\mathrm{E}_{\mathrm{s}}$ : Constrained modulus, $\mathrm{m}_{\mathrm{v}}$ : pore volume compressibility, $\mathrm{k}$ : permeability, $\phi$ : porosity, $G_{s}$ : specific gravity, $\mathbb{P}_{d}$ : dry density, D.C: dolomite cement, Mat.: matrix, Qz: quartz, R.F: rock fragments, Qz.RF: quartz + rock fragments, SubR: subrounded, SubA: subangular, $R_{d}$ : roundness scale, $S_{r}$ : sorting scale, mgs: mean grain size, $\mathrm{S}_{\mathrm{ph}}$ : sphericity, PD: packing density, PP: packing proximity, G.C: grain-cement contact, G.V: grain-void contact, G.G: grain-grain contact, Tot. Cement: total cement, Tot. Detritus: total detritus.

*Large Sig. (2-tailed) values implies non-significant relations and small correlation coefficient (R)values and vice versa.

\section{Petrographic Characteristics, Classification And Provenance Of Studied Sandstones}

The petrographic aspect of the studied sandstones was identified through the determination of mineralogical composition, textural and microstructure characteristics under the optical polarizing microscope. In the present study, the studied sandstone samples were classified mineralogically according to Folk (1974) and classified tectonically according to the tectonic discrimination fields described by Ingersoll and Suczek (1979).

Compositionally, the main detrital fraction of the studied sandstone is made up chiefly of quartz (from 25.5-78.5\% with an average of about $50.33 \%$ ), with lesser amounts of rock fragments (0.5-27.0\% with an average value of $7.43 \%$ ), silt and clay matrix (1.0-17\% with average of $5.45 \%$ ) and feldspars (microcline and plagioclase, $0.5-5.0 \%$ with average of $1.82 \%$ ), (Table 3).

In all studied sandstone samples, the cement materials are made up mainly of microsparite subhedral to euhedral crystalline zoned dolomite with ferron nuclei (10.0-35.5\% with average of $18.97 \%)$, some iron cementation materials mostly hematite and glauconite (0.5-10.0\% with average value of about $2.5 \%$ ) and subhedral to euhedral sparry calcite cement crystals that 
present only in one sample (S. No. 10). The skeleton fragments (pelecypod and algae) are generally rare in eleven samples with percentage ranging between $0.5 \%$ and $12.0 \%$ with an average of $3.78 \%$, these skeleton fragments are mostly replaced by microsparite dolomite crystals (Table 3 ).

The petrographic porosity that is discernable during the petrographic analysis under the optical polarizing microscope is generally ranging between $2.0 \%$ and $37.0 \%$ with an average of $12.7 \%$ (Table 3 ), the porosity in the studied sandstone samples is mostly categorized under fracture and interparticle porosity types with less intraparticle and vuggy porosity types.

The quartz grains in the studied sandstone samples are mostly monocrystalline and display unit and undulose extinction, while the polycrystalline rock fragments composed mainly of stretched subhedral to anhedral quartz crystals with suture contacts and undulose extinction. These detrital grains are characterized by frosted and fracturing surface features. So that, these characteristics of quartz and rock fragments indicated that these detrital grains are derived mainly from the Oligocene quartizite rocks which exposed south of study area and transported by wind "eolian transportation" to the depositional basin.

The quartz grains and rock fragments are floated in dense to very dense equigranular size crystals "uniform crystals" of euhedral to subhedral rhombic microsparite dolomite cement that corroded their peripheries. This indicated that the calcite cementation materials precipitated during the deposition of detrital sediments (Figs. 4 and 5) and the corrosion of detrital grains peripheries begin during dolomitization process. This appearance may be attributed to the growth of the cement forceful wedging a part of the detrital grains and corrosion of grains showing the presence of irregular and embayed contacts between cement and detrital grains (Waldschmidt, 1941).

According to Folk's classification (1974), the studied sandstones are classified as sublith-arenite, quartz arenite, litharenite, subarkose, and quartz wacke (Table 3).

The presence of algae and pelecypod skeleton fragments as well as glauconite pellets in the studied sandstones indicated that these rocks deposited under shallow marine environment. According to Ingersoll and Suczek (1979), the majority of the studied sandstones "17 samples" have recycle orogen and the other "4 samples" have craton interior orogen (Table 3 ). This tectonic setting classification revealed that, the studied sandstones were derived mainly from highly active tectonically areas south of Cairo-Ismailia road during late Oligocene time. The highly active tectonic sedimentary quartizite were eroded, weathered and recycled during early to middle Miocene time and deposited in shallow marine environment. This recycling origin evidenced by high alteration degree and surface feature of detrital grains in studied sandstones (Figs. 4 and 5, and Table 3).

Texturally, the mean grain size was determined in thin sections by using an ocular with millimeter scale. The mean grain size in the studied samples are ranging from $0.181 \mathrm{~mm}$ to $0.591 \mathrm{~mm}$ with an average value of about $0.278 \mathrm{~mm}$ (Table 3 ) which indicated that the size of detrital grains in the studied sandstones are ranging from fine to coarse sand size with majority of medium sand size, therefore the studied sandstones are considered as medium grained sandstones that agree with the study carried out by Abu-Zeid et al. (2004).

The detrital grains in the studied sandstones are of very elongated to equant sphericity with majority of sub-elongated grains, according to Folk (1974) the sphericity values ranging from 0.49 to 0.734 with average value of 0.647 .

\section{Table (3)}

Petrographic parameters of the studied sandstones. 


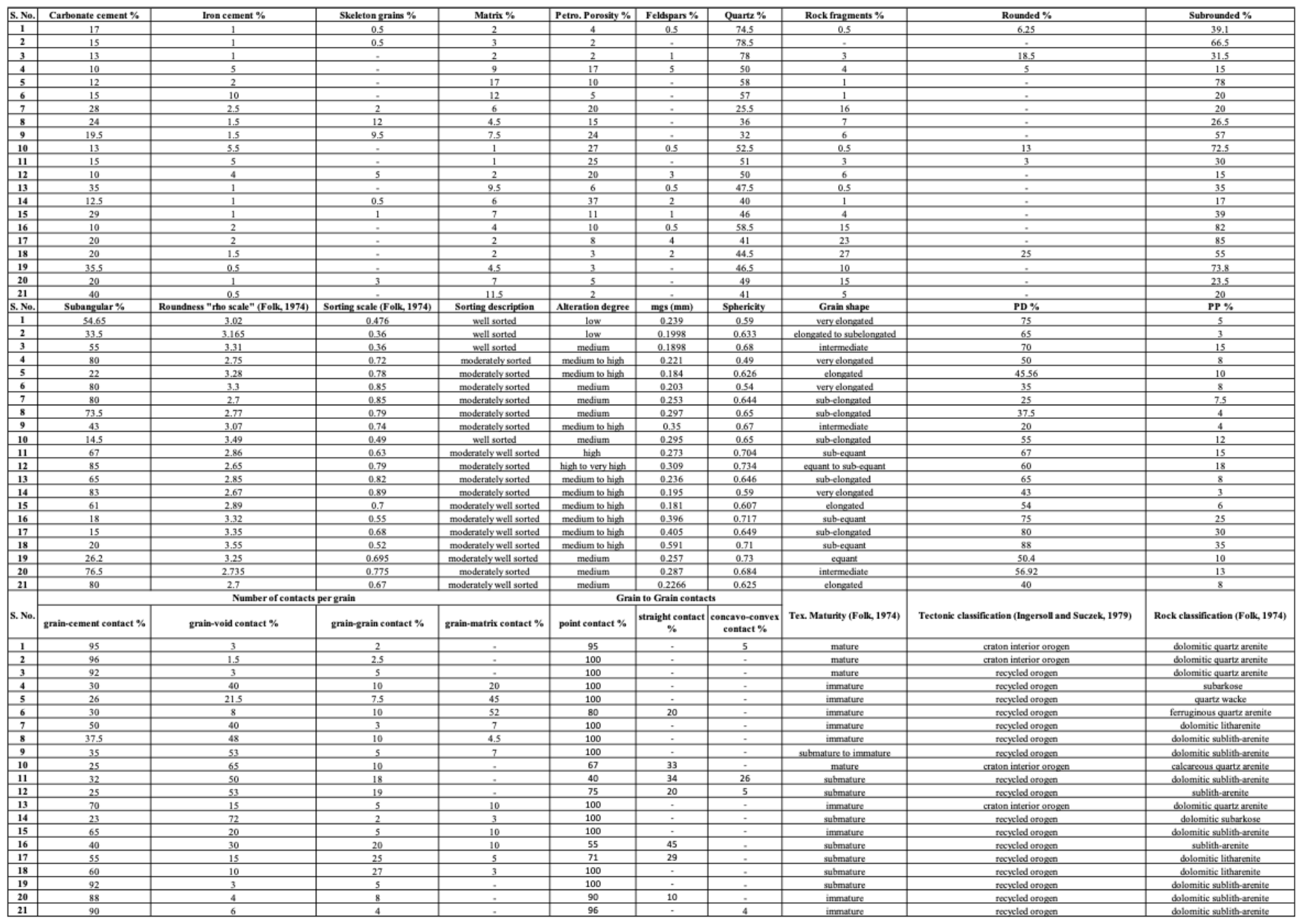

According to Power's (1953) classification, the majority of grains in the studied samples are ranging from subrounded to subangular with values range from $15.0-85.0 \%$ with an average of $44.07 \%$ and from $14.5-85.0 \%$ with average of $52.65 \%$, respectively. The rounded grains are recorded only in six studied samples with values $3.0-25.0 \%$ with average of $11.79 \%$ (Table 3). According to Folk's roundness scale, the roundness logarithmic rho scale for the studied sandstones is ranging from 2.65 to 3.55 with an average of 3.05 .

According to Folk's classification (1974), the sorting scale for the studied samples are ranging between 0.36 and 0.89 with an average value of about 0.673 , therefore the most of the studied sandstones ( 17 samples) are considered as moderately sorted to moderately well sorted, while the other samples (4 samples) are well sorted (Table 3 ).

In sandstone, the packing is the mutual relationships between the detritus grains. According to Kahn (1956) these relationships can be assessed in term of grain to grain contact or spacial relationship that expressed in term of packing proximity, in addition to closeness or spread grains or arrangement relationships expressed in term of packing density which defined as the occupied space of grains in a given area. The values of packing density (PD) and packing proximity (PP) are presented in table (3), where the PD values ranged from $20.0-88.0 \%$ with an average of $55.87 \%$ while the PP values ranged from $3.0-35.0 \%$ with an average value of $11.98 \%$. The lower values of PP indicated that, the detritus grains are mostly floated through the cement and matrix surrounding materials (Figs. 4 and 5).

Taylor (1950) was one of early researchers that measured the interlocking characteristics of grains in sandstones. She suggested that there are two measurements of grains interlocking which are number of contacts per grain "including grain to cement, grain to matrix, grain to grain, and grain to voids", and types of grain to grain contacts "including point, straight, concavo-convex, and sutured contacts". She also mentioned that the floating grains through cement and matrix materials 
and point contacts were due to original packing during depositional processes, the straight contacts due to original packing, overburden pressure, and cement precipitation; while the sutured and concavo-convex contacts were due to high overburden pressure. In this investigation, the grain to cement, grain to voids, and grain to matrix contacts are considered the most common types of grain contacts as shown in table (3) and figures (4 and 5); while the grain to grain contacts was the less common grain contact type with most common point and straight grain to grain contact types, respectively. These results revealed that the studied sandstones are characterized by floating or non-contacts grain interlocking with point and straight grain to grain contacts as well as the diagenesis processes of cementation were active during the early lithification stage (Table 3, and Figs. 4 and 5) which agree with the study of Bell and Lindsay (1999). The sutured contact type was observed only in rock fragments detritus grains which indicated that these rock fragments were derived mainly from metamorphic rocks. The concavo-convex was measured only in four samples (S.No. 1, 11, 12, and 21) which indicated that these samples influenced by notable overburden pressure.

According to Folk (1974), the texture maturity depends on matrix proportion, sorting degree and roundness characteristics of sandstones. The high content of matrix and moderately sorting and low roundness parameters of studied samples revealed that the majority of these studied sandstones are texturally immature and sub-mature (Table 3) that may be due to recycling of mixed sources "recycling of Oligocene quartizite and sand deposits as well as recycling of upper Eocene sandstone from south of the study area".

The petrographic characteristics of the studied sandstones were correlated with their physical and mechanical index properties by using regression analysis (Table 2). Because of the small amounts of skeleton fragments, feldspars and types of grain to grain contacts in the studied sandstones, they were not involved in this correlation analysis. The physical index properties as specific gravity, dry density, porosity and permeability exhibited weak to strong correlations with petrographic parameters where the specific gravity exhibited strong inverse relations with quartz contents and packing density with correlation coefficient $(R)$ values -0.625 and -0.783 , respectively, as well as exhibited moderate negative relations with packing proximity, roundness and grain to grain contacts with $R$ values of $-0.391,-0.299$, and -0.314 , respectively (Table 2 ). Also, the strong positive correlations of specific gravity with matrix content and sorting as well as moderate positive relation with dolomite cement content are represented in this study with $\mathrm{R}$ values $+0.511,+0.554$ and +0.391 , respectively (Table 2 ). The dry density exhibited moderate relationships with matrix content and sphericity with R values of +0.383 and -0.374 , respectively, while the porosity exhibited moderately inverse correlations with packing proximity, packing density and grain to cement contact as well as moderately positive relation with grain to void contacts (Table 2, and Figs. 6 and 7). The permeability had the inverse weak relation with packing density and inverse moderate relations with quartz and matrix contents, and grain to cement contact. On the other hand, it exhibited positive correlations with grain to voids contacts and petrographic porosity (Table 2, and Figs. 6 and 7).

Based on the regression analysis, the petrographic parameters of the studied sandstones as dolomite cement and matrix contents, quartz and rock fragments contents, packing density and proximity, sorting, roundness, mean grain size, and grain to cement contact exhibited weak to strong statistical correlations with mechanical properties with $\mathrm{R}$ values ranging from \pm 0.21 to \pm 0.534 as shown in table (2) and figures (8 and 9). These relationships revealed that due to the mineralogical, textural, and microstructure variations of the studied sandstones that had recycle origin, the non-significant to significant relations are resulted.

In addition to the effect of physical index properties on the petrographic parameters of the studied sandstones, these petrographic parameters had been affected by each other as tabulated in table (2), for instance, increasing of detritus grains as quartz and rock fragment grains, degree of roundness, grain to grain contact, mean grain size and sphericity may resulted in increasing the packing density and packing proximity, while the increasing of cement and matrix contents, sorting degree and petrographic porosity mostly resulted in decreasing the packing parameters. The roundness and sphericity are mostly increased with increase the mean grain size as well as the most textural parameters increase with increase the contents of detritus grains. The degree of sorting decreased with increase the quartz content, roundness and sphericity that emphasized the recycling origin of the studied sandstones.

Page 14/32 


\section{Multiple regression models}

The multiple regression analysis by using IBM SPSS statistics computer's software (V. 25) were conducted as the second stage of regression analyses. In this method, the purpose is to learn more about the relation between a dependent variable and several independent variables and to determine if these variables would define more significant relationships than single variable. This analysis is very important in reducing the independent variables to only a few variables that appropriately explain the variation in studied dependent variable, and then the derived empirical equation can be used in predict values of this dependent variable from the effective independent variables. In this study, the backward multiple regression was applied to predict the mechanical index parameters of the studied sandstones on the basis of their physical and petrographic characteristics by reduce the required number of measured variables in the multivariate linear regression without reducing the predictability, in addition to analyze and remove collinearity that may be exist between them.

The results of the multiple regression analysis for UCS and $m_{v}$ parameters are listed in tables (4 and 5), and the results of other $V_{p}$ and $E_{s}$ are obtained by the same manner. The backward multivariable linear regression method in this study was using the standard criteria to evaluate the statistical performance and to determine the all significant parameters of the regression as correlation coefficient, F-value (F-test), significant level, standard T-test (t-ratio), and 95\% confidence level of the regression analysis for each of engineering independent variable used in this regression and standard error of the estimate.

The F-test was performed to determine the regression significant, in addition to correlation coefficient of multiple determination $(R)$ whereas if the trend line is a good estimator for the data, the R will be near unity.

The importance of each independent variable was evaluated by examine the t-test, significant level, $95 \%$ confidence interval and sample partial regression coefficients associated with each.

The UCS has significant predictor which is $V_{p}$ with $R=+0.72$, and by increase the independent variables from one variable to four variables " $V_{p}, G_{s}, G . C$, and $S_{r}$ " resulted in an increase the $R$ from +0.72 to +0.818 , after that any increasing in variables accompanied with very small increase in predictive capability. On the other hand, the $\mathrm{m}_{\mathrm{v}}, \mathrm{G} . \mathrm{V}, \mathrm{Qz}$ content, and $\phi$ are considered good indicators of the UCS with regression coefficient $R=-0.858$ and any increasing in number of independent variables caused only a very small increasing in predictive capability (Table 4).

The multiple backward regression analysis showed that the $\mathrm{m}_{\mathrm{v}}$ can be estimated by using the seven good predictors "dolomite cement content, sub-rounded grain, mean grain size, quartz and rock fragment content, packing density, grain to cement and grain to grain contacts" with $\mathrm{R}=+0.821$. On the other hand, in the first step of analysis, the seven and/or the six independent variables predicted the $m_{v}$ with $R=-0.614$ and by decreasing the variables into five independent predictors the $R$ decreasing into -0.59 and when decreased into three and then into two variables the correlation coefficient values decreasing to -0.538 and -0.498 , respectively. So that, the UCS, matrix content, subangular grains, sorting degree, and grain to void contacts are considered as good predictors to estimate $m_{v}$ for the studied sandstones (Table 5).

For the $\mathrm{V}_{\mathrm{p}}$, an increase of independent variables from four to seven or six variables resulted in an increase in correlation coefficient value with less than of 0.021 . Therefore, the UCS, $G_{S}, \mathbb{P}_{d}$, and matrix content as well as $\phi, Q z \%$, SubA, and G.G contact are good predictors to estimate the $V_{p}$ of the studied sandstones with $R=+0.878$ and -0.805 , respectively. $A$ backward multiple regression performed for the $E_{S}$ indicates that the four variables UCS, $G_{S}, \mathbb{P}_{d}$, and matrix content as well as ф, Qz\%, SubA, and PP predicted this weak sandstone mechanical property with $\mathrm{R}=+0.873$ and -0.787 , respectively.

The multiple linear regression statistical performance for evaluation the engineering properties of the studied weak sandstones showed that the increasing of predictor variables number input into the regression models improve the estimating ability of UCS, $m_{v}, V_{p}$, and $E_{s}$. The most suitable prediction equations that represent the comparison of the best predictions of UCS, $m_{v}, V_{p}$, and $E_{s}$ properties of the studied weak sandstones by multiple regression analysis are listed in table (6).

Page $15 / 32$ 
Table (4)

Summary of multiple regression analysis for the studied sandstone UCS parameter.
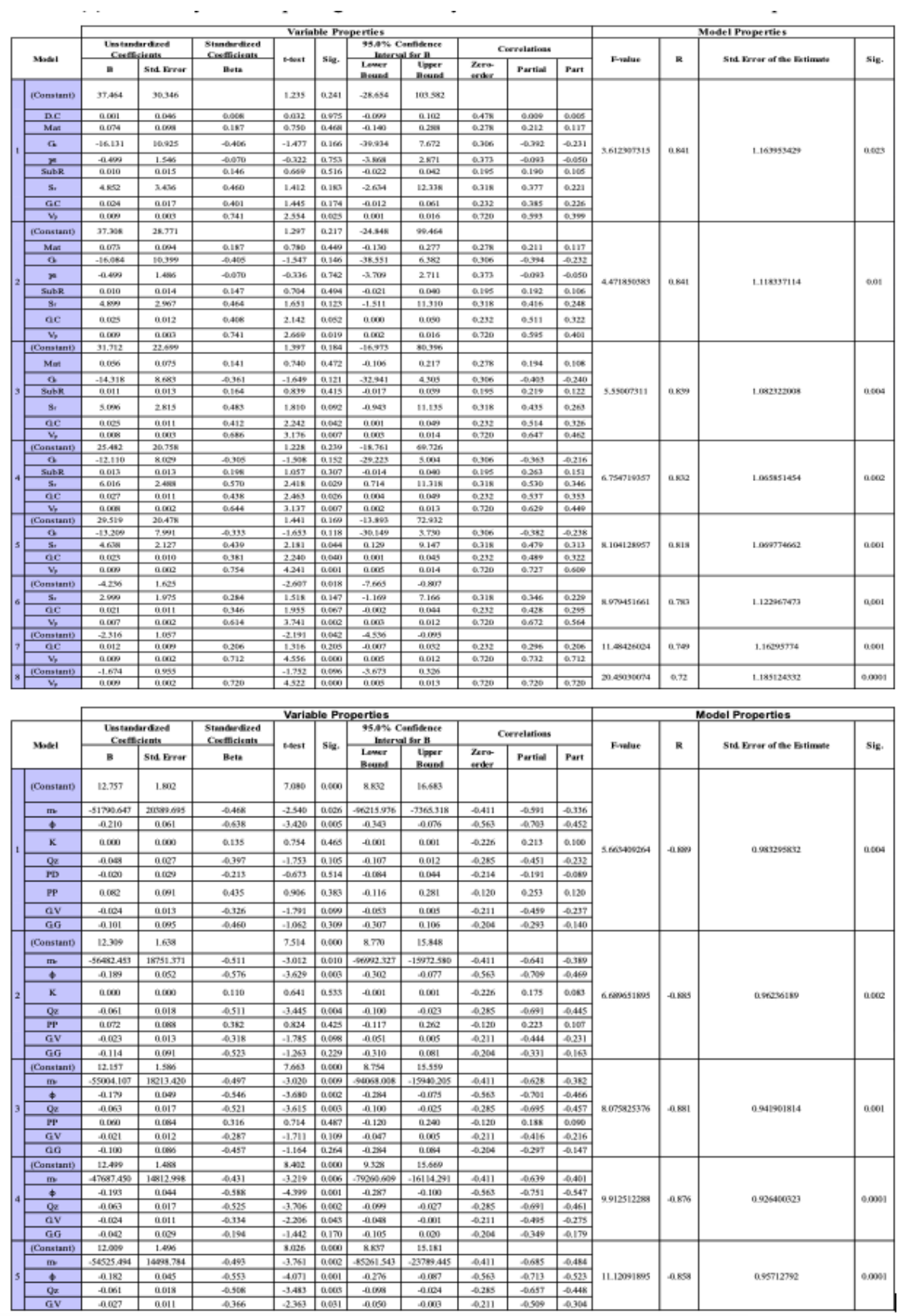

Table (5)

Summary of multiple regression analysis for the studied sandstone $\mathrm{m}_{\mathrm{v}}$ parameter. 


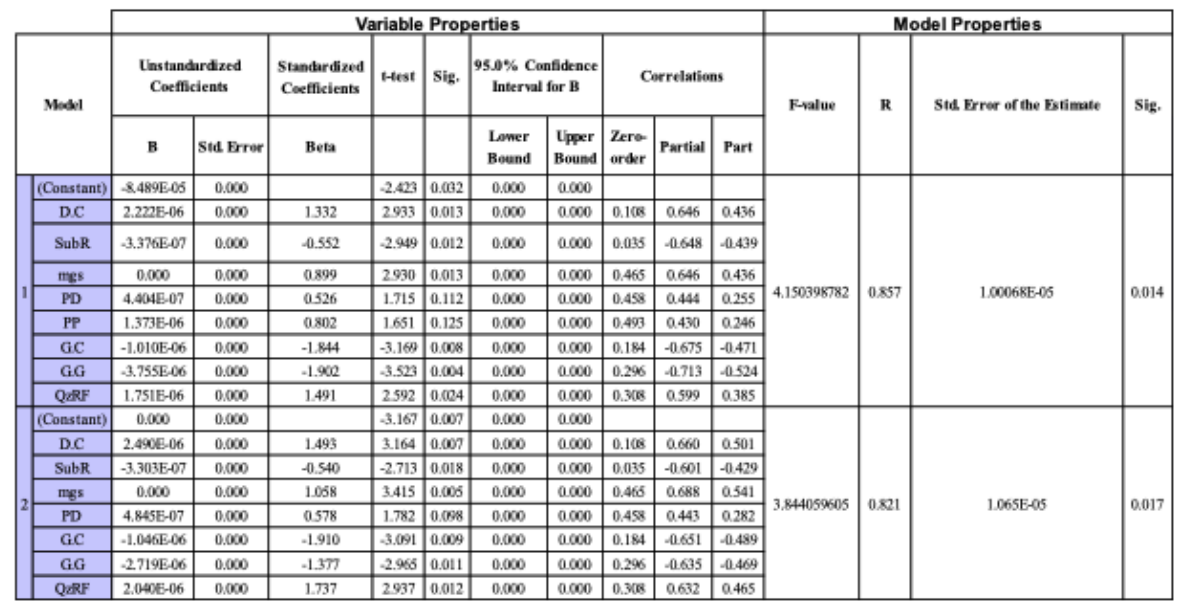

\begin{tabular}{|c|c|c|c|c|c|c|c|c|c|c|c|c|c|c|}
\hline \multirow{3}{*}{ Mostel } & \multicolumn{10}{|c|}{ Variable Properties } & \multicolumn{4}{|c|}{ Model Properties } \\
\hline & \multicolumn{2}{|c|}{$\begin{array}{l}\text { Unstandardized } \\
\text { Coeffidents }\end{array}$} & \multirow{2}{*}{$\begin{array}{c}\begin{array}{c}\text { Standardized } \\
\text { Ceefficients }\end{array} \\
\text { Beta }\end{array}$} & \multirow{2}{*}{ thest } & \multirow{2}{*}{ Sig. } & \multicolumn{2}{|c|}{$\begin{array}{c}95.0 \% \text { Confidence } \\
\text { Interval for B }\end{array}$} & \multicolumn{3}{|c|}{ Correlations } & \multirow{2}{*}{ Fvalue } & \multirow{2}{*}{$\mathbf{R}$} & \multirow{2}{*}{ Std Error of the Bstimate } & \multirow{2}{*}{ Sig. } \\
\hline & B & Std Error & & & & $\begin{array}{l}\text { Lowner } \\
\text { Bound }\end{array}$ & \begin{tabular}{|l|l} 
Upper \\
Bound
\end{tabular} & \begin{tabular}{|l|} 
Zero \\
arder
\end{tabular} & Partial & Part & & & & \\
\hline (Constant) & $4.1395-05$ & 0.000 & & \begin{tabular}{|l|}
0.127 \\
\end{tabular} & 0.901 & -0.001 & 0.01 & & & & \multirow{8}{*}{1.124427602} & \multirow{8}{*}{-0.614} & \multirow{8}{*}{ 1.47268E.66 } & \multirow{8}{*}{0.40} \\
\hline UCS & \begin{tabular}{|l|}
$-3,431 E-06$ \\
\end{tabular} & 0.000 & -0.350 & -0.900 & 0.345 & 0.000 & 0.000 & -0.411 & -0.262 & -0215 & & & & \\
\hline$v_{p}$ & $-2959 \mathrm{E}-08$ & 0.000 & -0.273 & -0.621 & 0.545 & 0.000 & $0 \omega 00$ & -0.443 & -0.170 & -0.136 & & & & \\
\hline $\mathrm{Mat}$ & $-1.248 E-06$ & 0.000 & -0.351 & \begin{tabular}{|l|l|}
-1.115 \\
\end{tabular} & 0.225 & 0.000 & 0,000 & -0.278 & -0.295 & -0244 & & & & \\
\hline SubA & \begin{tabular}{|l|l|}
$1.863 \mathrm{E}-07$ \\
\end{tabular} & 0.000 & -0.323 & \begin{tabular}{|l|}
1.052 \\
\end{tabular} & 0.294 & 0.060 & 0.000 & -0.157 & -0.290 & .0239 & & & & \\
\hline st & $4.1468-05$ & 0.000 & 0.435 & 1.065 & 0.311 & 0.000 & 0.000 & -0.279 & 0.281 & 0231 & & & & \\
\hline G & $3.4548=06$ & 0.060 & 0.010 & \begin{tabular}{|l|}
0.027 \\
\end{tabular} & 0.979 & 0.000 & 0.000 & -0.320 & 0.008 & 0.006 & & & & \\
\hline GV & \begin{tabular}{|l|l|}
$2635 E-07$ \\
\end{tabular} & 0.000 & -0.401 & $\mid-1.351$ & 0.200 & 0.000 & 0.000 & -0.189 & -0351 & -0296 & & & & \\
\hline (Constant) & $5.022 E-05$ & 0.060 & & 27993 & 0.014 & 0.000 & 0,00 & & & & \multirow{7}{*}{ 1.,412590398 } & \multirow{7}{*}{$\mid-0.614$} & \multirow{7}{*}{ 1.41915E-05 } & \multirow{7}{*}{$0.2 \pi$} \\
\hline UCS & $-3.466 \mathrm{E}-06$ & 0.000 & -0.384 & -1.105 & 0.288 & 0.000 & 0,000 & -0411 & -02283 & -0.233 & & & & \\
\hline$v_{p}$ & $2878 \mathrm{EE}-08$ & 0.000 & -0.266 & -0.802 & 0.436 & 0.060 & 0,000 & -0.443 & -0.209 & -0.169 & & & & \\
\hline Mat & $-1.238 E-06$ & 0.000 & -0.349 & -1.214 & 0.245 & 0.000 & 0.000 & -0.278 & -0.309 & -0.256 & & & & \\
\hline SubA & \begin{tabular}{|l|l|}
$1.855 E-07$ \\
\end{tabular} & 0.000 & -0.322 & $\mid-1.149$ & 0.270 & 0.000 & 0.000 & $-a 157$ & -0.294 & -0.242 & & & & \\
\hline Sorting & $4.16 \pi=-05$ & 0.000 & 0.437 & \begin{tabular}{|l|}
1.121 \\
\end{tabular} & 0.281 & 0.000 & 0.000 & -0.279 & 0.287 & 0.236 & & & & \\
\hline $\mathrm{GV}$ & $-2642 \mathrm{E} 07$ & 0.060 & -0.402 & -1.416 & 0.179 & 0.060 & 0.000 & -0.189 & -0354 & .0299 & & & & \\
\hline (Constant) & 4.211E-05 & 0.060 & & \begin{tabular}{|l|}
28699 \\
\end{tabular} & 0.012 & 0.000 & 0.000 & & & & \multirow{6}{*}{1.604809403} & \multirow{6}{*}{-0.59} & & \\
\hline UCS & \begin{tabular}{|l|l|}
$5.135 \mathrm{E} .06$ \\
\end{tabular} & 0.000 & -0.568 & -2.216 & 0.043 & 0.060 & 0.000 & -0.411 & -0.497 & 0.402 & & & & \\
\hline Mat & -1.257E.06 & 0.000 & -0.354 & -1.249 & 0.231 & 0.060 & 0000 & .0278 & .0 .307 & -02260 & & & 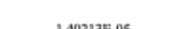 & | \\
\hline SubA & \begin{tabular}{|l|l|}
$-1.548 E-07$ \\
\end{tabular} & 0.000 & -0.268 & -1.000 & 0.333 & 0.000 & 0.000 & -0.157 & -0250 & -02008 & & & $1.402150-03$ & \\
\hline St & \begin{tabular}{|l|l|}
$3.845 E-05$ \\
\end{tabular} & 0.000 & 0.403 & 1.064 & 0.309 & 0.060 & $0 \omega 00$ & -0.279 & 0.263 & 0.220 & & & & \\
\hline $\mathrm{GV}$ & \begin{tabular}{|l|}
$3.00 \mathrm{EE}-07$ \\
\end{tabular} & 0.060 & -0.458 & -1.605 & 0.113 & 0.000 & 0,000 & -0.189 & -0.399 & -0.351 & & & & \\
\hline \begin{tabular}{|l|} 
COnstant) \\
\end{tabular} & $4.3560-05$ & 0.000 & & \begin{tabular}{|l|}
2983 \\
\end{tabular} & 0.009 & 0.000 & 0.000 & & & & & & & \\
\hline UCS & $-4.240 \mathrm{E} .06$ & 0.000 & -0.469 & -1.984 & 0.065 & 0.060 & $0 \omega 00$ & \begin{tabular}{|l|l|} 
\\
\end{tabular} & -0.444 & -0414 & & & & \\
\hline Mat & \begin{tabular}{|l|}
$-1.131 E-06$ \\
\end{tabular} & 0.000 & -0.319 & \begin{tabular}{|l|}
-1.1333 \\
\end{tabular} & 0.274 & 0.000 & 0.000 & -0.278 & -0.272 & -0.236 & 1.756220558 & $-0.552 \mid$ & $1.40211 \mathrm{E}-05$ & 0.187 \\
\hline $\mathrm{S}_{\mathrm{r}}$ & 1.818E-05 & 0.000 & 0.191 & \begin{tabular}{|l|}
0.599 \\
\end{tabular} & 0.558 & 0.000 & 0.000 & -0.279 & 0.148 & 0.125 & & & & \\
\hline $\mathrm{GV}$ & $-2667 \mathrm{E}-07$ & 0.060 & -0.406 & -1.520 & 0.148 & 0.000 & 0,000 & -0.189 & -0.355 & -0317 & & & & \\
\hline (Constant) & \begin{tabular}{|l|l|}
$5.081 E-05$ \\
\end{tabular} & 0.000 & & \begin{tabular}{|l|}
6.337 \\
\end{tabular} & 0.000 & 0.000 & 0,000 & & & & & & & \\
\hline UCS & \begin{tabular}{|l|l|}
$3.776 E-06$ \\
\end{tabular} & 0.060 & -0.418 & \begin{tabular}{|l|}
-1.933 \\
\end{tabular} & 0.000 & 0.000 & 0.000 & -0411 & -0.424 & -0.395 & 23017006 & | & $137445-5$ & 0113 \\
\hline Mat & \begin{tabular}{|l|l|}
$.539 \mathrm{E} .07$ \\
\end{tabular} & 0.000 & -0.212 & -0.992 & 0.335 & 0.060 & 0.000 & -0.278 & -0.234 & -0.203 & 2.401006 & $|-0.538|$ & 1.3754110005 & 0.113 \\
\hline $\mathrm{GV}$ & $-20400-07$ & 0.000 & -0.311 & $-1,4 \pi$ & 0.158 & 0.000 & 0000 & -0.189 & -0.337 & \begin{tabular}{|l|}
-0302 \\
\end{tabular} & & & & \\
\hline (Constant) & \begin{tabular}{|l|l|}
$4.7346-05$ \\
\end{tabular} & 0.060 & & \begin{tabular}{|l|}
65576 \\
\end{tabular} & 0.000 & 0.060 & 0,000 & & & & & & & \\
\hline UCS & \begin{tabular}{|l|l|}
$-4.266 \mathrm{E}-06$ \\
\end{tabular} & 0.000 & -0.472 & -2.258 & 0.037 & 0.000 & 0000 & -0.411 & -0.470 & \begin{tabular}{|l|}
-0.461 \\
\end{tabular} & 2.974972104 & -0.458 & $1.374766-05$ & 0.077 \\
\hline $\mathrm{GV}$ & \begin{tabular}{|l|l|}
$1.892 \mathrm{E} .07$ \\
\end{tabular} & 0.060 & -0.288 & \begin{tabular}{|l|l|}
-1.378 \\
\end{tabular} & 0.185 & 0.060 & 0000 & -0.189 & -0.309 & -0282 & & & & \\
\hline (Constant) & \begin{tabular}{|l|}
$4.06 S E-05$ \\
\end{tabular} & 0.060 & & \begin{tabular}{|l|}
72866 \\
\end{tabular} & 0.000 & 0.060 & 0.000 & & & & 5104 & 414 & Lataten & $0 \times 4$ \\
\hline UCS & \begin{tabular}{|l|l}
$.717 \mathrm{E}-06$ \\
\end{tabular} & 0.000 & -0.411 & -1.966 & 0.054 & 0.000 & \begin{tabular}{|l|}
0.000 \\
\end{tabular} & -0411 & -0.411 & -0.411 & 73104 & 0.441 & 1.406040 .00 & .054 \\
\hline
\end{tabular}

\section{Table (6)}

The best multiple regression analysis equations to predict the mechanical engineering index properties 


\begin{tabular}{|c|c|c|}
\hline $\begin{array}{l}\text { Eng. } \\
\text { Parameter }\end{array}$ & Equation & $\mathbf{R}$ \\
\hline \multirow[t]{8}{*}{ UCS } & 0.124 (pet. Ф)-0.064 (G.V)-0.029 (PD)-0.298 (Ф) + 10.343 & -0.912 \\
\hline & $-0.027(\mathrm{G} . \mathrm{V})-0.06(\mathrm{Qz})-0.182(\phi)-54525.49\left(\mathrm{~m}_{\mathrm{v}}\right)+12.009$ & -0.858 \\
\hline & 0.1 (Mat) $+0.047($ D.C $)+0.009\left(\mathrm{~V}_{\mathrm{p}}\right)-14.89\left(\mathrm{G}_{\mathrm{s}}\right)+36.797$ & $\stackrel{+}{0.801}$ \\
\hline & $8.53\left(S_{r}\right)+0.034($ SubR $)+0.36($ G.C) -6.66 & +0.71 \\
\hline & -0.0455 (PD)-0.252 (ф)-0.0374 (Tot. Detritus) + 13.479 & -0.795 \\
\hline & 0.068 (G.G) + 0.137 (pet. Ф)-5.158 (mgs)-0.0734 (G.V)-0.024 (PD)-0.338(ф) + 11.64 & -0.935 \\
\hline & $0.009\left(V_{p}\right)+0.023(G . C)+4.638\left(S_{r}\right)-13.21\left(G_{s}\right)+29.519$ & $\stackrel{+}{0.818}$ \\
\hline & $0.008\left(V_{p}\right)+0.027(G . C)+6.016\left(S_{r}\right)+0.013($ SubR $)-12.11\left(G_{s}\right)+25.5482$ & $\stackrel{+}{0.832}$ \\
\hline \multirow[t]{6}{*}{$\mathrm{m}_{\mathrm{v}}$} & $\begin{array}{l}\left(2.49 * 10^{-6}\right)(\text { D.C })-(3.3 * 10-7)(\text { SubR })+\left(0.16^{\star} 10-3\right)(\mathrm{mgs})+(4.85 * 10-7)(\mathrm{PD})-\left(1.05^{\star} 10^{-6}\right)(\mathrm{G} . \mathrm{C})- \\
\left(2.72 * 10^{-6}\right)(\mathrm{G} . \mathrm{G})+\left(2.04^{\star} 10^{-6}\right)(\mathrm{QzRF})-0.00011\end{array}$ & $\stackrel{+}{0.821}$ \\
\hline & $\begin{array}{l}\left(3.85^{\star} 10^{-5}\right)\left(\mathrm{S}_{\mathrm{r}}\right)-\left(5.14^{\star} 10^{-6}\right)(\mathrm{UCS})-\left(1.26 * 10^{-6}\right)(\mathrm{Mat})-\left(1.55^{*} 10^{-7}\right)(\mathrm{SubA})-\left(3.008^{*} 10^{-7}\right)(\mathrm{G} . \mathrm{V})+ \\
\left(4.21 * 10^{-5}\right)\end{array}$ & -0.59 \\
\hline & $\left(5.43^{\star} 10^{-5}\right)(\mathrm{mgs})-\left(3.74 * 10^{-8}\right)\left(\mathrm{V}_{\mathrm{p}}\right)-\left(7.06 * 10^{-7}\right)(\mathrm{UCS})+\left(2.99 * 10^{-5}\right)$ & -0.698 \\
\hline & $\left(5.54 * 10^{-5}\right)(\mathrm{mgs})-\left(4.35^{\star} 10^{-8}\right)\left(\mathrm{V}_{\mathrm{p}}\right)+\left(3.088^{*} 10^{-5}\right)$ & -0.694 \\
\hline & $\left(1.29 * 10^{-6}\right)(\mathrm{PP})+\left(3.78^{\star} 10^{-5}\right)(\mathrm{mgs})-\left(1.25^{\star} 10^{-6}\right)(\mathrm{G} . \mathrm{G})+\left(1.147 * 10^{-5}\right)$ & $\stackrel{+}{0.612}$ \\
\hline & $\left(-1.09 * 10^{-4}\right)\left(\mathrm{G}_{\mathrm{s}}\right)-\left(3.77 * 10^{-6}\right)(\mathrm{UCS})-\left(5.87 * 10^{-7}\right)($ Tot. Detritus $)+\left(3.75^{\star} 10^{-4}\right)$ & -0.644 \\
\hline \multirow[t]{5}{*}{$V_{p}$} & $43.43(\mathrm{UCS})+1941.46\left(\mathrm{G}_{\mathrm{s}}\right)+190.78\left(\mathbb{P}_{\mathrm{d}}\right)-11.96($ Mat $)-5214.687$ & $\stackrel{+}{0.878}$ \\
\hline & $-8.26(\phi)-7.397(Q z)-2.31($ SubA)-9.08(G.G) + 1248.33 & -0.81 \\
\hline & $1301.12\left(G_{s}\right)+49.95(U C S)-3167.65$ & $\stackrel{+}{0.812}$ \\
\hline & $-4.598(\mathrm{PD})-2.32(\mathrm{SubA})+859.83$ & -0.56 \\
\hline & $-9.05(\phi)-5.819(Q z)+973.99$ & -0.626 \\
\hline \multirow[t]{4}{*}{$E_{s}$} & $0.093(\mathrm{UCS})+3.428\left(\mathrm{G}_{\mathrm{S}}\right)+0.494\left(\mathbb{P}_{\mathrm{d}}\right)-0.026(\mathrm{Mat})-9.866$ & $\stackrel{+}{0.873}$ \\
\hline & $-0.027(\phi)-0.014(\mathrm{Qz})-0.005($ SubA) $-0.016(\mathrm{PP})+2.261$ & -0.787 \\
\hline & $1.986\left(G_{s}\right)+0.112(U C S)-5.128$ & $\stackrel{+}{0.782}$ \\
\hline & $-0.024(\phi)-0.0117(Q z)+1.653$ & -0.654 \\
\hline
\end{tabular}

\section{Conclusion remarks}

The evaluation of physico-mechanical, ultrasonic wave velocity and compressibility characteristics of weak sandstones is carried out in this study, as well as the relationships between their petrographic characteristics and their engineering index parameters were quantified by a comprehensive bivariant and multivariant statistical regression analyses. Quantification of 
the mineralogical and textural parameters by using optical microscope had allowed to identification of these petrographic parameters that control the mechanical, wave velocity and compressibility performance of these weak sandstones.

This study demonstrated that, the studied sandstones are high to very high porous sandstones with very low to moderate density. The unconfined compressive strength of the studied sandstones is varied from $0.34 \mathrm{MPa}$ to $6.89 \mathrm{MPa}$, the ultrasonic P-wave velocity and constrained modulus are varied from $213.97 \mathrm{~m} / \mathrm{s}$ to $703.7 \mathrm{~m} / \mathrm{s}$; and from $0.09 \mathrm{GPa}$ to $1.03 \mathrm{GPa}$, respectively. Therefore, the studied sandstone rocks are classified as extremely weak to weak rocks with very high deformability and very low wave velocity.

The study revealed that, the physical properties of the studied rocks form non-significant linear relations with UCS, $V_{p}$, and $E_{s}$ and these relations improved by execution of non-linear exponential, logarithmic, polynomial and power regression models. The uniaxial pore volume compressibility for the studied sandstones are ranging from $10.54^{\star} 10^{-6} \mathrm{Psi}^{-1}$ to $69.12^{\star} 10^{-6} \mathrm{Psi}^{-1}$ and are classified as friable sandstones to unconsolidated sandstones with high deformability. The uniaxial pore volume compressibility forms weak linear inverse correlations with the physical parameters of studied sandstones. The study founded that there are moderately strong to strong correlations between P-wave velocity, constrained modulus, unconfined compressive strength and compressibility characteristics of studied weak sandstones.

Petrographically, the studied sandstones are classified as shallow marine, moderately sorted to moderately well sorted, immature to sub-mature sublith-arenite, quartz arenite, litharenite, subarkose, and quartz wacke. These sandstones are chiefly made up of quartz (from 25.5-78.5\%) with lesser amounts of rock fragments (0.5-27.0\%), silt and clay matrix (1.0-17.0\%) and feldspars (microcline and plagioclase, $0.5-5.0 \%$ ). The cement materials are mainly made up of microsparite subhedral to euhedral crystalline zoned dolomite with ferron nuclei (10.0-35.5\%), and the petrographic porosity is mostly categorized under fracture and interparticle porosity types with less intraparticle and vuggy porosity types (2.0-37.0\%). The quartz grains in the studied sandstone samples are mostly monocrystalline and commonly display unit and wavy extinction, while the polycrystalline rock fragments composed mainly of stretched subhedral to anhedral quartz crystals with suture contacts and undulose extinction. These indicated that the detrital grains are derived mainly from the Oligocene quartizite that exposed south of study area and transported by wind "eolian transportation" to the depositional basin.

The bivariant analysis represented that the specific gravity exhibited strong inverse relations with quartz content and packing density, as well as exhibited moderate negative relations with packing proximity, roundness and grain to grain contacts. The dry density exhibited moderate relationships with matrix content and sphericity, while the porosity exhibited moderately inverse correlations with packing proximity, packing density and grain to cement contact as well as moderately positive relation with grain to void contact. The permeability had the inverse weak relation with packing density and inverse moderate relations with quartz and matrix contents, and grain to cement contact; on the other hand, it exhibited positive correlations with grain to void contact and petrographic porosity. Based on the regression analysis, the dolomite cement and matrix contents, quartz and rock fragments contents, packing density and proximity, sorting, roundness, mean grain size, and grain to cement contact exhibited weak to strong statistical correlations with mechanical properties of the studied sandstones. These wide range of non-significant to significant relationships were mostly due to the mineralogical, textural, and microstructure variations of the studied sandstones that had recycle origin.

The study suggested that the increasing of detritus grains as quartz and rock fragment grains, degree of roundness, grain to grain contact, mean grain size and sphericity may resulted in increasing the packing density and packing proximity, while the increasing of cement and matrix contents, sorting degree and petrographic porosity mostly resulted in decreasing the packing parameters. The roundness and sphericity are mostly increased with increase the mean grain size as well as the most textural parameters increase with increase the contents of detritus grains. The degree of sorting decreased with increase the quartz content, roundness and sphericity that emphasized the recycling origin of the studied sandstones.

In this study, the backward multiple regression analysis was applied to predict the unconfined compressive strength, pore volume compressibility, wave velocity and constrained modulus of the studied sandstones by selecting some physical and 
petrographic characteristics which exhibit statistically significant correlations with them. The use of backward multiple statistics is very important by reducing the required number of measured variables in the multivariate linear regression without reducing the predictability, in addition to analyze and remove collinearity that may be exist between them. This multiple regression analysis demonstrated that the $V_{p}, G_{s}, G . C$ and $S_{r}$ as well as $m_{v}, G . V$, Qz content and $\phi$ are considered good indicators for the UCS with regression coefficient +0.818 and -0.858 , respectively, and any increasing in number of independent variables caused only a very small increasing in predictive capability. The multiple backward regression analysis showed that, the $\mathrm{m}_{\mathrm{v}}$ can be estimated by using the seven good predictors "dolomite cement content, sub-rounded grain, mean grain size, quartz and rock fragment content, packing density, grain to cement and grain to grain contacts" with $\mathrm{R}=+0.821$. On the other hand, the UCS, matrix content, subangular grains, sorting degree, and grain to void contact are considered as good predictors to estimate $m_{v}$ for the studied sandstones with correlation coefficient -0.59 .

For the $\mathrm{V}_{\mathrm{p}}$ and $\mathrm{E}_{\mathrm{s}}$, an increase of independent variables from four to seven or six variables resulted in an increase in correlation coefficient values with less than of 0.021 . Therefore, the UCS, $G_{S}, \mathbb{P}_{d}$, and matrix content as well as $\phi, Q z \%$, SubA, and G.G contact are good predictors to estimate the $V_{p}$ of the studied sandstones.

The multiple linear regression statistical performance for evaluation the engineering properties of the studied weak sandstones showed that the increasing of predictor variables number input into the regression models improve the estimating ability of UCS, $m_{v}, V_{p}$, and $E_{s}$. The results of this study were presented in the form of predictive models and equations.

\section{Declarations}

\section{Acknowledgments}

The authors acknowledge the scientific and financial supports of this work from the Basic Sciences Sector (SDAC), Ain Shams University “Project: Sustainable Development of El-Obour City, East of Greater Cairo, Egypt” 2008-2011.

\section{Declaration of interest:}

The authors declare that they have no known competing financial interests or personal relationships that could have appeared to influence the work reported in this paper.

\section{References}

Abdel-Aaal, M. H., Abd-Allah, A. M. A., and Khafagy, A. A. B. (2004): Compressive strength of some carbonate rocks; problems and measurements. J. Appl. Geophys. V. 3(2), pp. 27-41.

Abu Seif, E. S. (2016): Evaluation of geotechnical properties of Cretaceous sandstone, western desert, Egypt. Arab. J. Geosci. V. 9:299. 13 P. DOI: https://doi.org/10.1007/s12517-016-2317-x.

Abu-Zeid, M. M., El-Nahhas, F. M., Dowidar, H. M., and Hashem, W. A. (2004): Petrography and engineering geology of the foundation bedrocks in El-Obour area, east of Cairo, Egypt. Mid. East Res. Cent. (M.E.R.C.), Ain Shams Univ., Earth Sci. Ser. V. 18. pp. 81-105.

Altindag, R, (2012): Correlation between P-wave velocity and some mechanical properties for sedimentary rocks. J. South Afr. Inst. Min. Metall. V. 112(3). pp.229-237. On-line version ISSN 2411-9717.

American Society for Testing and Materials (ASTM), (2003): Annual book of ASTM standard. Standard test method for laboratory determination of pulse velocities and ultrasonic elastic constants of rock (D 2845-00). West Conshohocken, PA, USA. 
American Society for Testing and Materials (ASTM), (2018): Annual book of ASTM standard. Standard test method for laboratory determination of density (unit weight) of soil specimens (D7263-09). West Conshohocken, PA, USA.

American Society for Testing and Materials (ASTM), (2003): Annual book of ASTM standard. Standard test method for specific gravity of soil solids (D 854-00). West Conshohocken, PA, USA.

Azimian, A., Ajalloeian, R., and Fatehi, L. (2014): An empirical correlation of uniaxial compressive strength with P-wave velocity and point load strength index on marly rocks using statistical method. J. Geotech. Geol. Eng. V. 32(1). pp. $205-214$. DOI: https://doi.org/10.1007/s10706-013-9703-x.

Azimian, A., and Ajalloeian, R. (2015): Empirical correlation of physical and mechanical properties of marly rocks with P wave velocity. Arab. J. Geosci. V.8(4). pp. 2069-2079. DOI: https://doi.org/10.1007/s12517-013-1235-4.

Bell, F. G. (1978): The physical and mechanical properties of the fell sandstones, Northumberland, England. J. Eng. Geol. V.12. pp. 1-29. DOI: https://doi.org/10.1016/0013-7952(78)90002-9.

Bell, F. G. (1983): Fundamentals of engineering geology, Butterworth-Heinemann (Pub.), London. 648 P.

Bell, F. G., and Lindsay, P. (1999): The petrographic and geomechanical properties of some sandstones from the Newspaper Member of the Natal Group near Durban, South Africa. J. Eng. Geol. V.53(1). pp. 57-81. DOI: https://doi.org/10.1016/S00137952(98)00081-7.

Blatt, H. (1982): Sedimentary petrology: W. H. Freeman and Company (Pub.), New York, pp. 105-143.

Chen, H., and Ye Hu, Z. (2001): A preliminary study on the relationship between engineering properties and uniaxial compressive strength of weak sandstones. Western Pacific Earth Sci. V.1(3). pp. 297-338.

Christensen, N. I. (2004): Serpentinites, peridotites and seismology. Inter. Geol. Rev. V.46(9). pp.795-816. DOI: https://doi.org/10.2747/0020-6814.46.9.795.

Compton, R. R. (1962): Manual of field geology: John Wiley and Sons (Pub.). New York. 378 P.

Diamantis, K., Gartzos, E., and Migiros, G. (2009): Study on uniaxial compressive strength, point load strength index, dynamic and physical properties of serpentinites from Central Greece: test results and empirical relations. J. Eng. Geol. V. 108(3-4). pp.199-207. DOI: https://doi.org/10.1016/j.enggeo.2009.07.002.

Dobereiner, L., and De Freitas, M. H. (1986): Geotechnical properties of weak sandstone. J. Géotechnique. V. 36(1). pp.79-94. DOI: https://doi.org/10.1680/geot.1986.36.1.79.

Egyptian Code (2007): Soil mechanics, design and construction foundation. Site investigations, Part 1, Code No. 1/202. Building and Housing Research Center. Cairo, Egypt.

Egyptian Code (2007): Soil mechanics, design and construction foundation. Laboratory tests, Part 2, Code No. 2/202. Building and Housing Research Center. Cairo, Egypt.

El-Belasy, M. I. (1986): Geology of Gebel Hamza-Um Qamar area, Cairo-Ismailia district, Egypt, M.Sc. Thesis, Faculty of Science, Cairo Univ. 185 P.

Escartin, J., Hirth, G., and Evans, B. (2001): Strength of slightly serpentinized peridotites: implications for the tectonics of oceanic lithosphere. J. Geol. V.29(11). pp. 1023-1026. DOI: https://doi.org/10.1130/0091-

7613(2001)029<1023:SOSSPI>2.0.CO;2. 
Fahy, M. P., and Guccione, M. J. (1979): Estimating the strength of sandstone using petrographic thin section data. Bull. Assoc. Eng. Geol. V.16 (4). pp. 467-485. DOI: https://doi.org/10.2113/gseegeosci.xvi.4.467.

Folk, R. L. (1974): Petrology of sedimentary rocks. $2^{\text {nd }}$ Ed., Hemphill Publishing Company (Pub.), Austin, Texas, USA. 184 P. Fratta, D., and Santamarina, J. C. (1996): Wave propagation in soils: multi-mode, wide-band testing in a waveguide device. Geotech. Test. J., GTJODJ. V.19(2). pp. 130-140. American Society for Testing and Materials. West Conshohodten, PA. DOI: https://doi.org/10.1520/GTJ10336J.

Geertsma, J. (1966): Problems of rock mechanics in petroleum production engineering. Proc. $1^{\text {st }}$ ISRM Congress. Lisbon, Portugal. Document ID: ISRM-1CONGRESS-1966-099. pp. 585-594.

Geertsma, J. (1973): Land subsidence above compacting oil and gas reservoirs. J. Petrol. Technol. V. 25(6). pp. 734 -744. Document ID: SPE-3730-PA. DOI: https://doi.org/10.2118/3730-PA.

Heidari, M., Momeni, A. A., Rafiei, B., Khodabakhsh, S., and Torabi-Kaveh, M. (2013): Relationship between petrographic characteristics and the engineering properties of Jurassic sandstones, Hamedan, Iran. J. Roc. Mech. \& Roc. Eng. V.

46(5). $\quad$ pp. 1091-1101. DOI: https://doi.org/10.1007/s00603-012-0333-z.

Howarth, D. F., and Rowlands, J. C. (1986): Development of an index to quantify rock texture for qualitative assessment of intact rock properties: Geotech. Test. J., GTJODJ. V.9(4). pp. 169-179. DOI: https://doi.org/10.1520/GTJ10627J.

Hutchinson, C. S. (1974): Laboratory handbook of petrography techniques. Wiley (Pub.). New York. 527 P.

Ingersoll, R. V., and Suczek, C. A. (1979): Petrology and provenance of Neogene sand from Nicobar and Bengal fans. DSDP sites 211 and 218. J. Sed. Petro. V.49(4). pp. 1217-1228. DOI: https://doi.org/10.1306/212F78F1-2B24-11D78648000102C1865D.

International Association of Engineering Geology (IAEG), (1979): Classification of rocks and soils for engineering geological mapping. Part I: Rock and soil materials. Bull. Inter. Assoc. Eng. Geol. No. 19. pp. 364-371.

International Society for Rock Mechanics (ISRM), (1981): Suggested method for rock characterization, testing and monitoring, ISRM Commission on Testing Methods: Brown E.T. (ed.), Oxford: Pergamon Press, 211 P.

International Society for Rock Mechanics (ISRM), (2007): The complete ISRM suggested methods for rock characterization, testing and monitoring: 1974-2006. In: Ulusay and Hudson (Eds.) Suggested methods prepared by the commission on testing methods. International Society for Rock Mechanics. ISRM Turkish National Group, TUKMD, Ankara, Turkey. 628 P.

Jeng, F. S., Weng, M. C., Lin, M. L., and Huang, T. H. (2004): Influence of petrographic parameters on geotechnical properties of tertiary sandstones from Taiwan. J. Eng. Geol. V.73(1-2). pp 71-91. DOI: https://doi.org/10.1016/j.enggeo.2003.12.001.

Kahn, J. S. (1956): The analysis and distribution of the properties of packing in sand-size sediments: 1 . On the measurement of packing in sandstones. J. Geol. V.64(4). pp. 385-395. DOI: https://doi.org/10.1086/626372.

Khandelwal, M. (2013): Correlating P-wave velocity with the physico-mechanical properties of different rocks. Pure \& Appl. Geophys. V. 170(4), pp. 507-514. DOI: https://doi.org/10.1007/s00024-012-0556-7.

Ktena, St., and Sabatakakis, N. (2013): Correlation between mechanical and petrographic parameters of sandstones. Bull. Geol. Soc. Greece. V. 47 (3). pp. 1726-1730. DOI: https://doi.org/10.12681/bgsg.11051.

Kurtuluş, C., Sertçelik, F., and Sertçelik, I. (2016): Correlating physico-mechanical properties of intact rocks with P-wave velocity. J. Acta Geod. Geophys. V.51(3). pp.571-582. DOI: https://doi.org/10.1007/s40328-015-0145-1.

Page 22/32 
Vutukuri, V. S., Lama, R. D., and Saluja, S. S. (1978): Handbook on mechanical properties of rocks: testing techniques and results. Volume 2. Trans. Tech. Publications. In: Series on rock and soil mechanics, V.3(1). Cleveland, Ohio, Bay Village, Ohio. $495 \mathrm{P}$.

Meng, Z., Zhang, J., and Peng, S. (2006): Influence of sedimentary environments on mechanical properties of clastic rocks. J. Env. Geol. V.51. pp.113-120. DOI: https://doi.org/10.1007/s00254-006-0309-y.

Moradian, Z. A., and Behnia, M. (2009): Predicting the uniaxial compressive strength and static young's modulus of intact sedimentary rocks using the ultrasonic test. Inter. J. Geomech. (@ASCE). V.9(1). pp. 14-19. DOI: 10.1061/(ASCE)15323641(2009)9:1(14).

Nassif, A. (2003): Stress-strain relationship for weak rocks. In: Di Benedetto, H., Doanh, T., Geoffroy, H., and Sauzèat, C. (Eds.), Deformation Characteristics of Geomaterials. Swets \& Zeitlinger, Lisse. ISBN 9058096041. pp. 415-419.

Nefeslioglu, H. A. (2013): Evaluation of geo-mechanical properties of very weak and weak rock materials by using nondestructive techniques: Ultrasonic pulse velocity measurements and reflectance spectroscopy. J. Eng. Geol. V. 160. pp. 8-20. DOI: https://doi.org/1 0.1016/j.enggeo.2013.03.023.

Newman, G. H. (1973): Pore-volume compressibility of consolidated, friable, and unconsolidated reservoir rocks under hydrostatic loading. Document ID: SPE-3835-PA. J. Petrol. Techn. V.25(2). pp. 129-134. DOI: https://doi.org/10.2118/3835-PA.

Nikraz, H. R., Evans, A. W., and Press, M. E. (2012): Effects of mine dewatering on poorly consolidated sandstone. Inter. Mine Water Assoc. (IMWA). www.IMWA.info. pp. 143-153.

Nikraz, H. R., Press, M., and Evans, A. (1995): Prediction of land subsidence caused by mine dewatering. Proceedings of the $5^{\text {th }}$ Inter. Sympo. on land subsidence, the Hague. IAHS Pub. No. (234). pp. 197-206.

Olivera, R. (1993): The engineering geology of weak rock "chapter 1: weak rock materials". Cripps et al. (eds.). Eng. Geol. Spec. Publ. Series 8. pp. 5-15. ISBN 90619116.

Othman, B. S., and Ali, D. K. (2017): Correlation study some dynamic properties with density, point load index and uniaxial compressive strength of some units of Mukdadya (lower Bakhtiari) Formation. Tikrit J. Pure Sci. V. 22 (6). pp. 81-87. ISSN: 1813-1662 (Print), E-ISSN: 2415-1726.

Pettijohn, F. J., Potter, P. E., and Siever, R. (1987): Sands and sandstones. $2^{\text {nd }}$ Ed. Springer-Verlag Berlin Heidelberg New York (Pub.). 553 P. ISBN: 978-1-4612-1066-5 (eBook). DOI: https://doi.org/10.1007/978-1-4612-1066-5.

Powers, M. C. (1953): A new roundness scale for sedimentary particles: J. Sed. Petro. V.23(2). pp. 117-119. https://doi.org/10.1306/D4269567-2B26-11D7-8648000102C1865D.

Sabatakakis, N., Tsiambaos, G., and Gerochristodoulou, D. (2002): Estimation of physical and mechanical parameters of rock material. Bull. of the Public Works Central Laboratory of Greece (KEDE), special edition. pp. 3-8.

Said, R. (1990): The geology of Egypt: A. A. Balkema (Pub.), Rotterdam, Netherlands. 734 P. ISBN: 9061918561.

Sarkar K., Vishal V., and Singh T. N. (2012): An empirical correlation of index geomechanical parameters with the compressional wave velocity. J. Geotech. \& Geol. Eng. V.30(2). pp. 469-479. DOI: https://doi.org/10.1007/s10706-011-9481-2.

Shakoor, A., and Bonelli, R. E. (1991): Relationship between petrographic characteristics, engineering index properties, and mechanical properties of selected sandstones. Bull. Assoc. Eng. Geol. V.28(1). pp. 55-

71.

DOI: https://doi.org/10.2113/gseegeosci.xxviii.1.55. 
Sharma, P. K., and Singh, T. N. (2008): A correlation between P-wave velocity, impact strength index, slake durability index and uniaxial compressive strength. Bull. Eng. Geol. \& Environ. V.67(1). pp. 17-22. DOI: https://doi.org/10.1007/s10064-007-0109y.

Shukri, N. M. (1953): The geology of the desert east of Cairo. Bulletin de l'Institut du Desert d'Egypte. V.3(2). pp. 89-105.

Shukri, N. M., and Akmal, M. G. (1953): The geology of Gebel El-Nasuri and Gebel El-Anqabiya district. Bulletin de la Societe de Geographie d'Egypte. V.26. pp. 243-276.

Singh, T. N., Verma, A. K., Singh, V., and Sahu, A. (2005): Slake durability study of shaly rock and its predictions. J. Envir. Geol. V.47(2). pp. 246-253. DOI: https://doi.org/10.1007/s00254-004-1150-9.

Starzec, P. (1999): Dynamic elastic properties of crystalline rocks from south-west Sweden. Inter. J. Rock Mech. \& Min. Sci. V.36 (2). pp. 265-272. PII: S0148-9062(99)00011-X.

Swedan A. H. (1991): A note on the geology of Greater Cairo area. Annals of the geological survey of Egypt, V.17, pp. $239-251$.

Taylor, J. M. (1950): Pore-space reduction in sandstones. Bull. American Assoc. Petrol. Geolo. V.34(4). pp. 701-716. DOI: https://doi.org/10.1306/3D933F47-16B1-11D7-8645000102C1865D.

Teeuw, D. (1971): Prediction of formation compaction from laboratory compressibility data. Soc. Petrol. Eng. J. V.11(3). pp. 263-271. Document ID: SPE-2973-PA. DOI: https://doi.org/10.2118/2973-PA.

Tucker, M. E. (2003): Sedimentary rocks in the Field (The Geological Field Guide series). $3^{\text {rd }}$ Ed. Chichester: Wiley (Pub.), 234 P. ISBN 0470851236.

Ulusay R., Türeli, K., and Ider, M. H. (1994): Prediction of engineering properties of a selected litharenite sandstone from its petrographic characteristics using correlation and multivariate statistical techniques. J. Eng. Geol. V.38(1-2). pp. 135-157. DOI: https://doi.org/10.1016/0013-7952(94)90029-9.

Waldschmidt, W. A. (1941): Cementing materials in sandstones and their probable influence on migration and accumulation of oil and gas. Bull. Amer. Assoc. Petrol. Geol. V25(10). pp. 1839-1879. DOI: https://doi.org/10.1306/3D9333F6-16B1-11D78645000102C1865D.

Yagiz, S. (2011): P-wave velocity test for assessment of geotechnical properties of some rock materials. Bull. Mater. Sci. V.34(4). pp.947-953. DOI: https://doi.org/10.1007/s12034-011-0220-3.

Yar, M., Arif, M., Afridi, A. K., Saeed, M., Ziad, M., and Ali, A. (2017): Petrographic and mechanical properties of sandstone from Murree Formation, Jena Kor Area, Peshawar Basin. A case study. Pak. J. Engg. \& Appl. Sci. V. 20. pp. 69-78.

Yasar, E. and Erdogan, Y. (2004): Correlating sound velocity with the density, compressive strength and young's modulus of carbonate rocks. Inter. J. Roc. Mech. \& Min. Sci. V.41(5). pp. 871-875. DOI: https://doi.org/10.1016/j.ijrmms.2004.01.012.

\section{Figures}




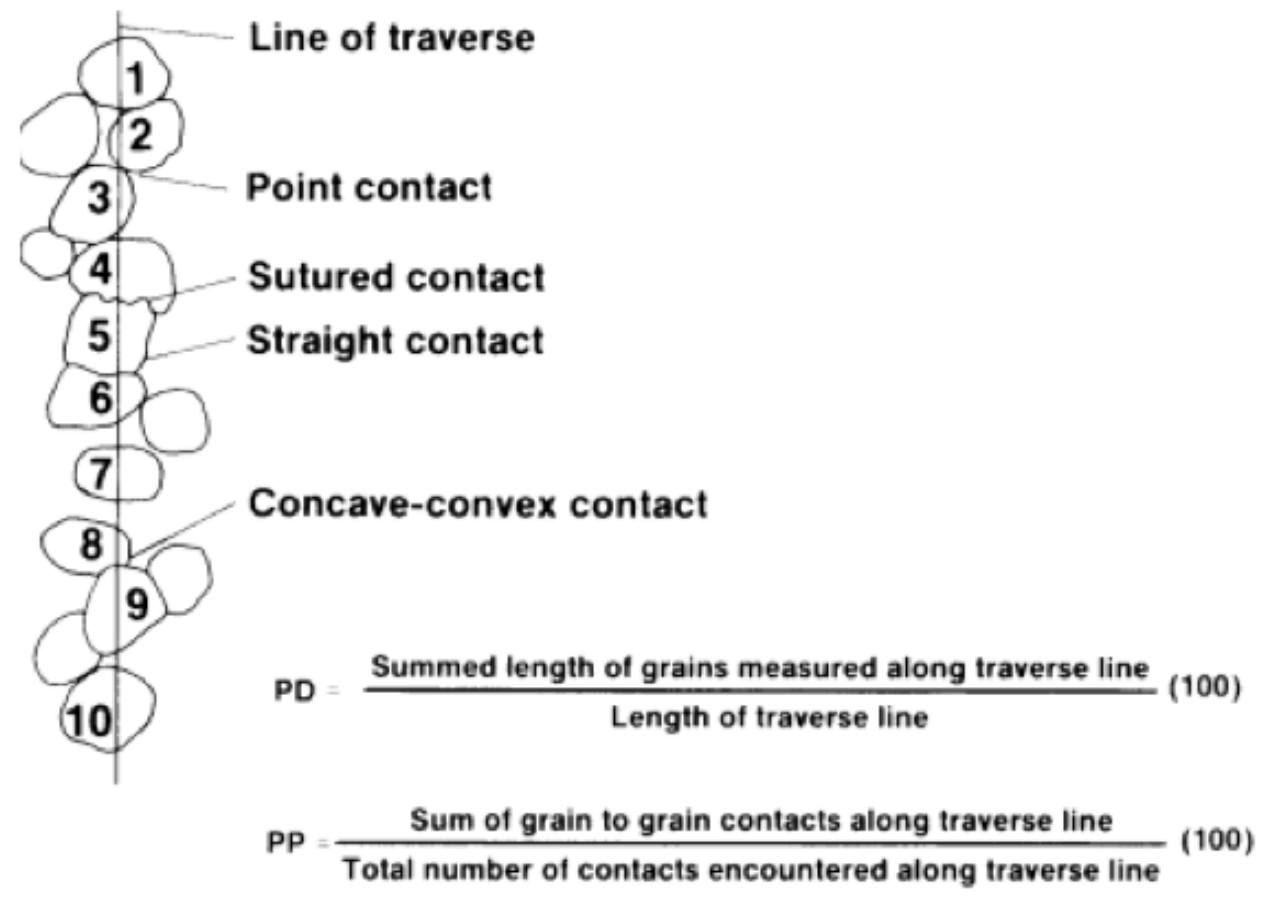

Figure 1

Definition of Packing density and packing proximity according to Kahn (1956) and classification of grain - grain contacts according to Blatt (1982). 


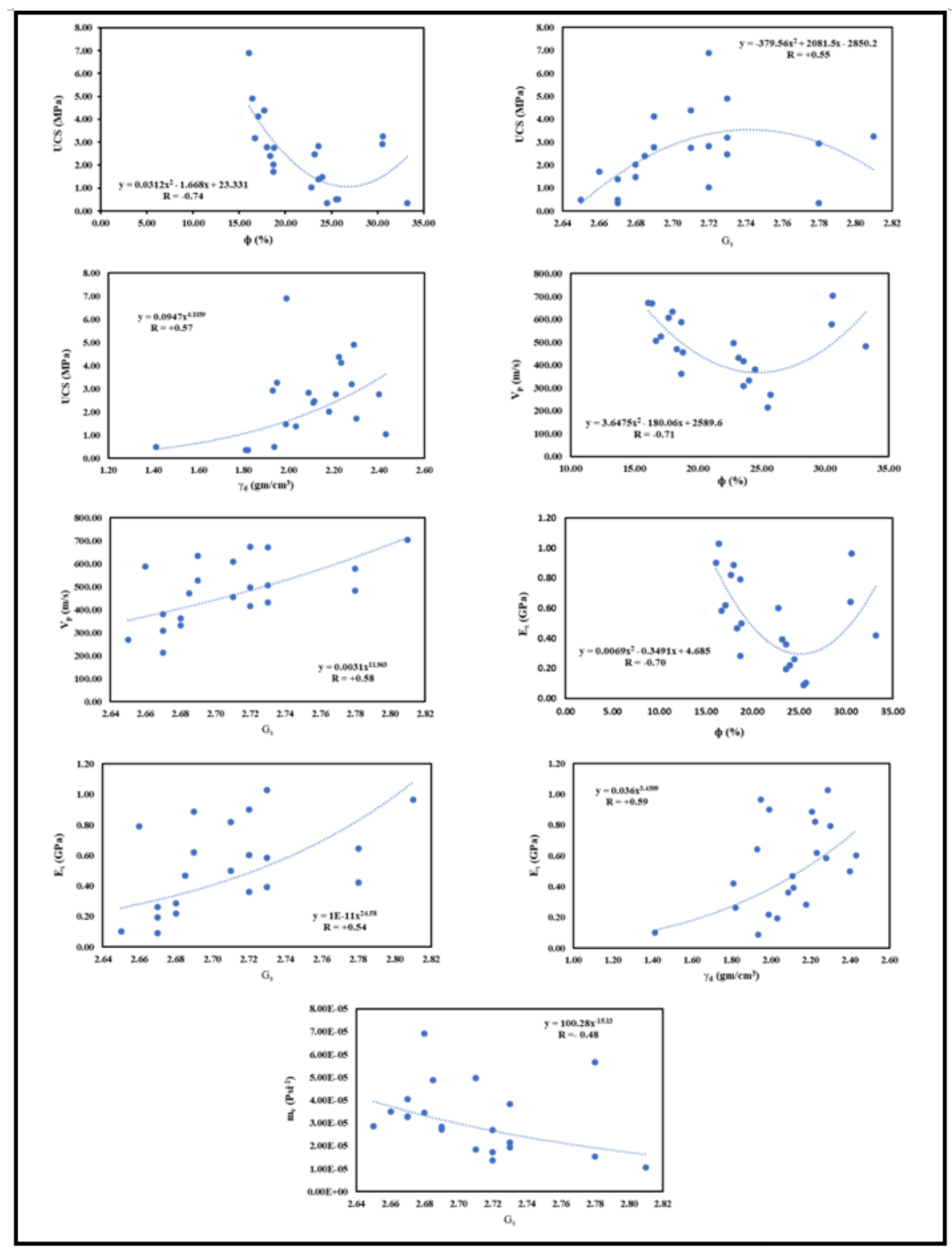

Figure 2

Bivariant relationships of physical parameters with UCS, Vp, Es and mv properties of studied sandstones. 


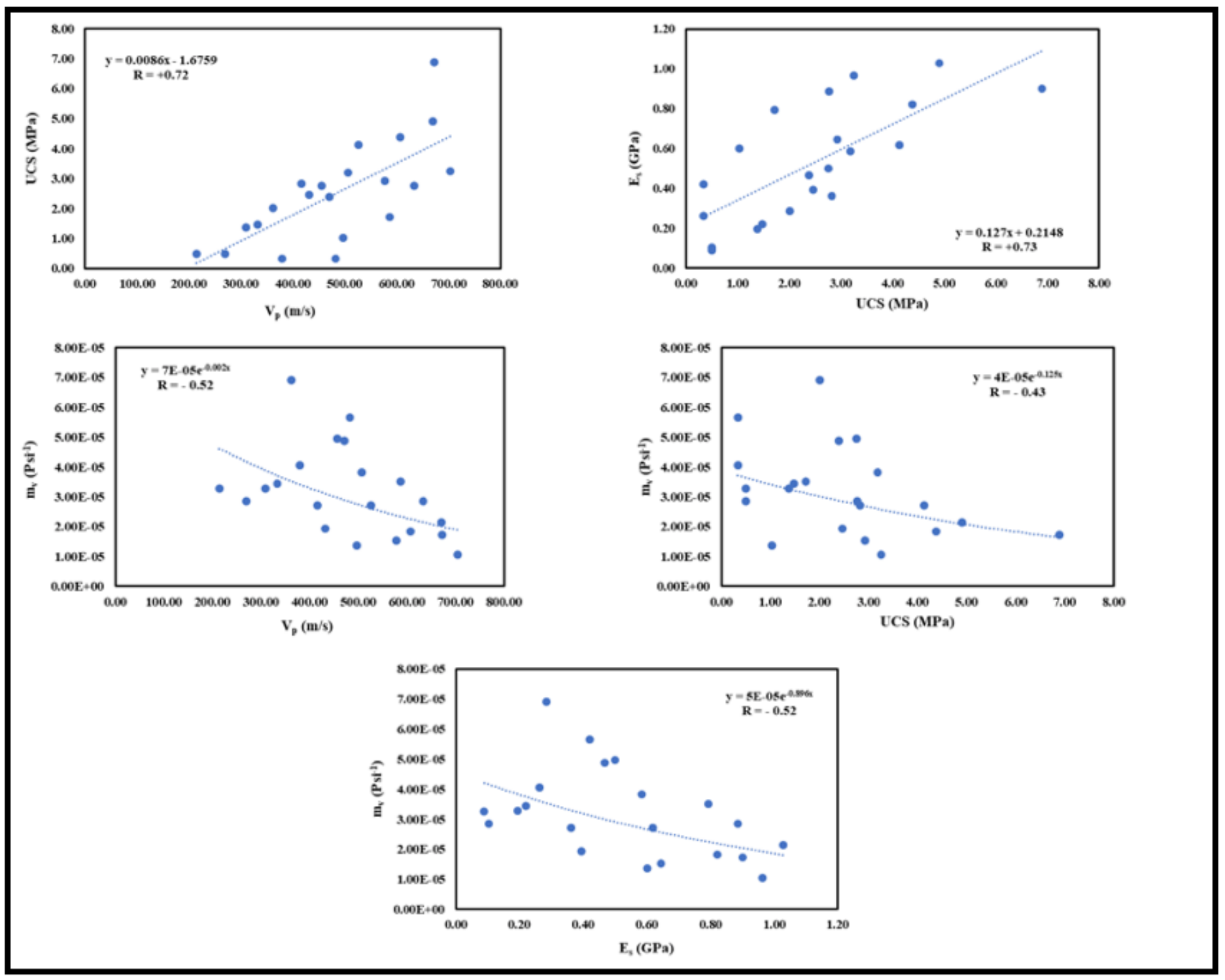

Figure 3

Bivariant relationships between UCS, Vp, Es and mv properties of studied sandstones. 

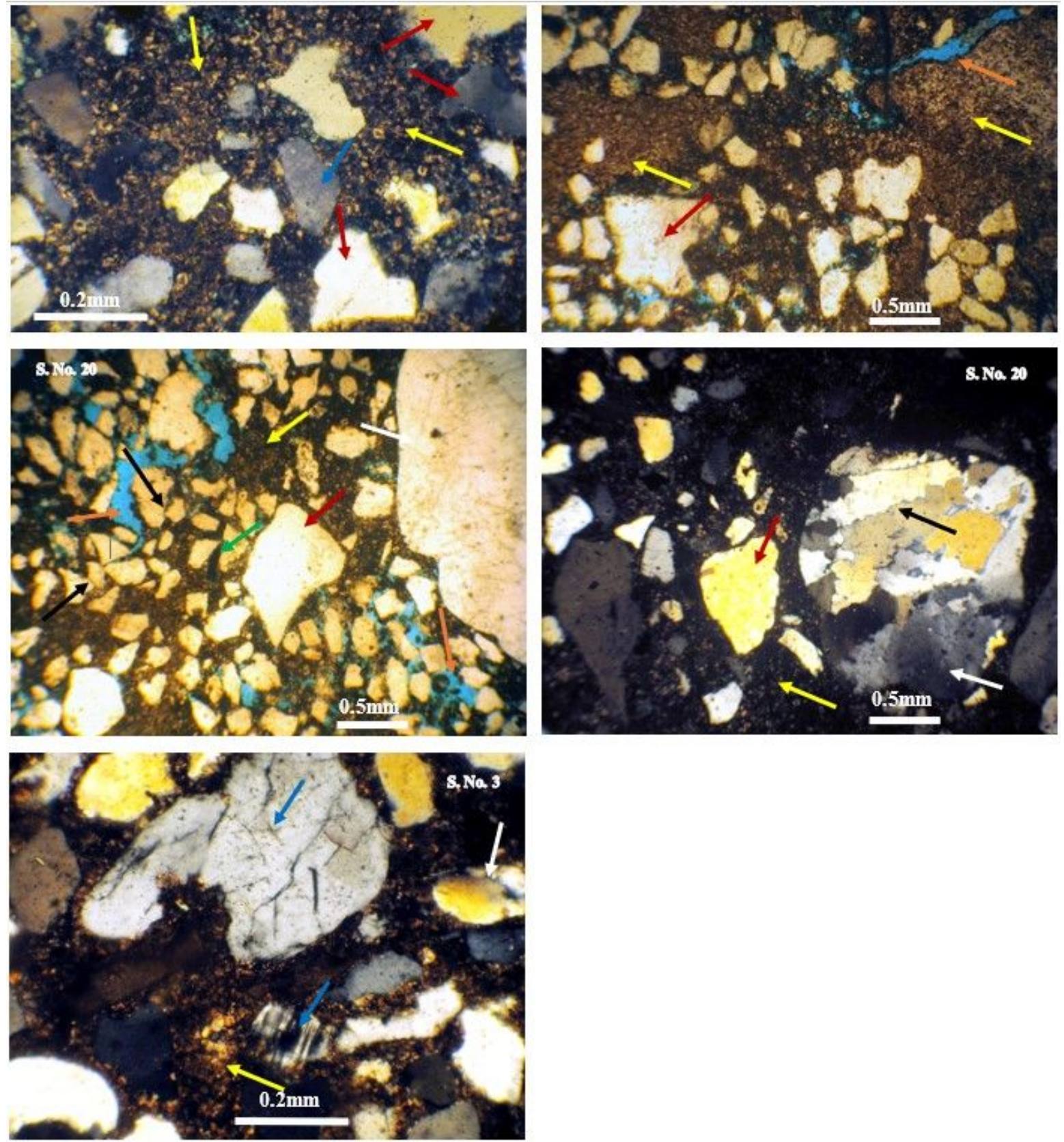

\section{Figure 4}

Photomicrographs of dolomitic sublith-arenite (S. No. 19, 20 and 21) and dolomitic quartz-arenite (S. No. 3) under PPL and C.N, the rocks consist of sub-angular to sub-rounded monocrystalline quartz grains (red arrow), sub-rounded polycrystalline rock fragments with undulose extinction (white arrow), and altered microcline feldspar (blue arrow), the peripheries of detritus grains are corroded by dolomite cement. The detrital grains are floated in the dense fine subhedral dolomite cement (yellow arrow) and iron oxides cement (green arrow), and showing fracture and inter-particles porosities (orang arrow). The figures show moderately packing density, low packing proximity, high grain to cement contact and low grain to grain contact with point and straight contacts between quartz grains, and sutured contacts within rock fragment grains (black arrow). PPL: Plane Polarized Light C.N: Crossed Nicols 

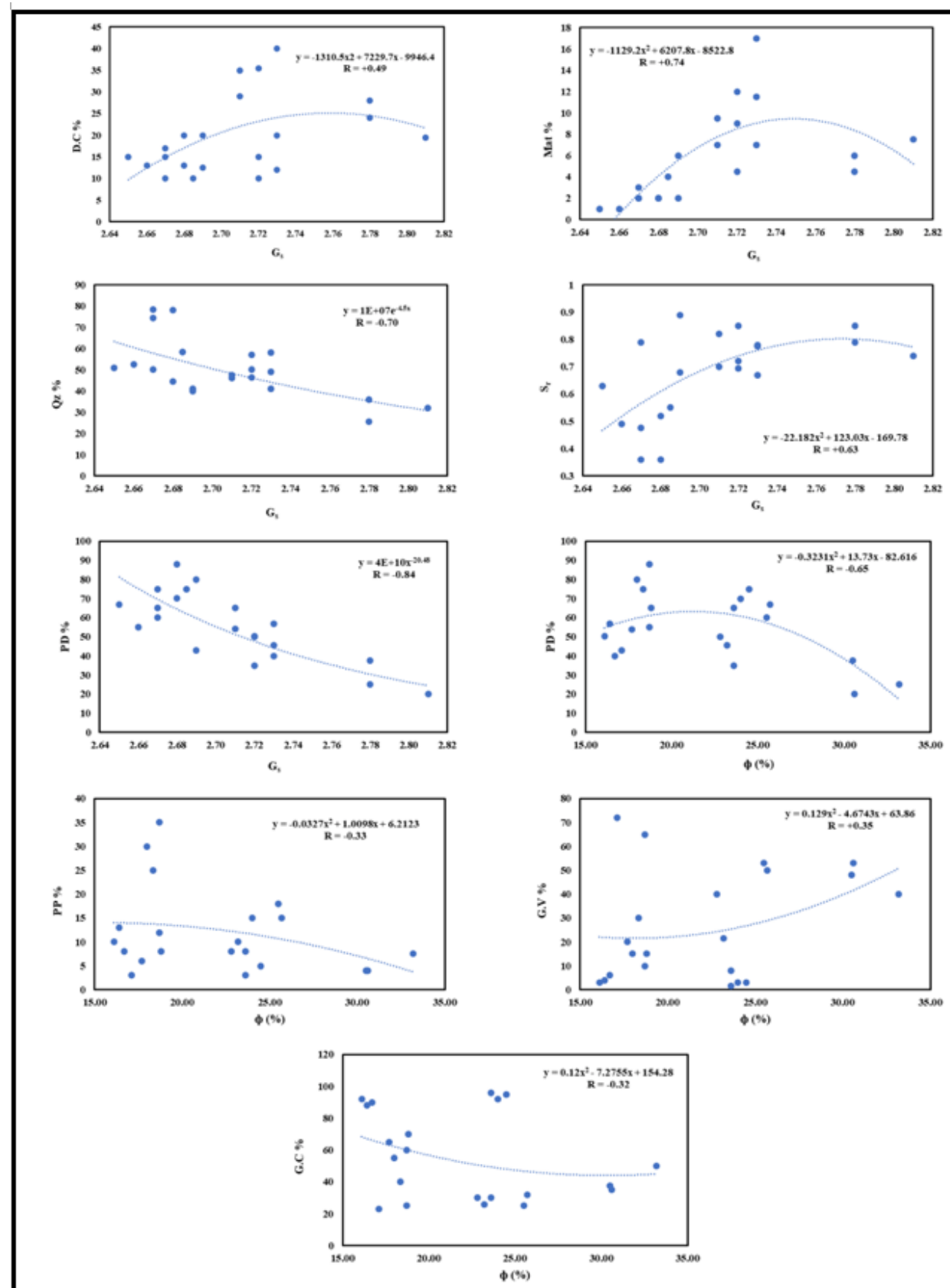

Figure 6

Bivariant relationships of some petrographic parameters with $\phi$ and Gs properties of studied sandstones. 


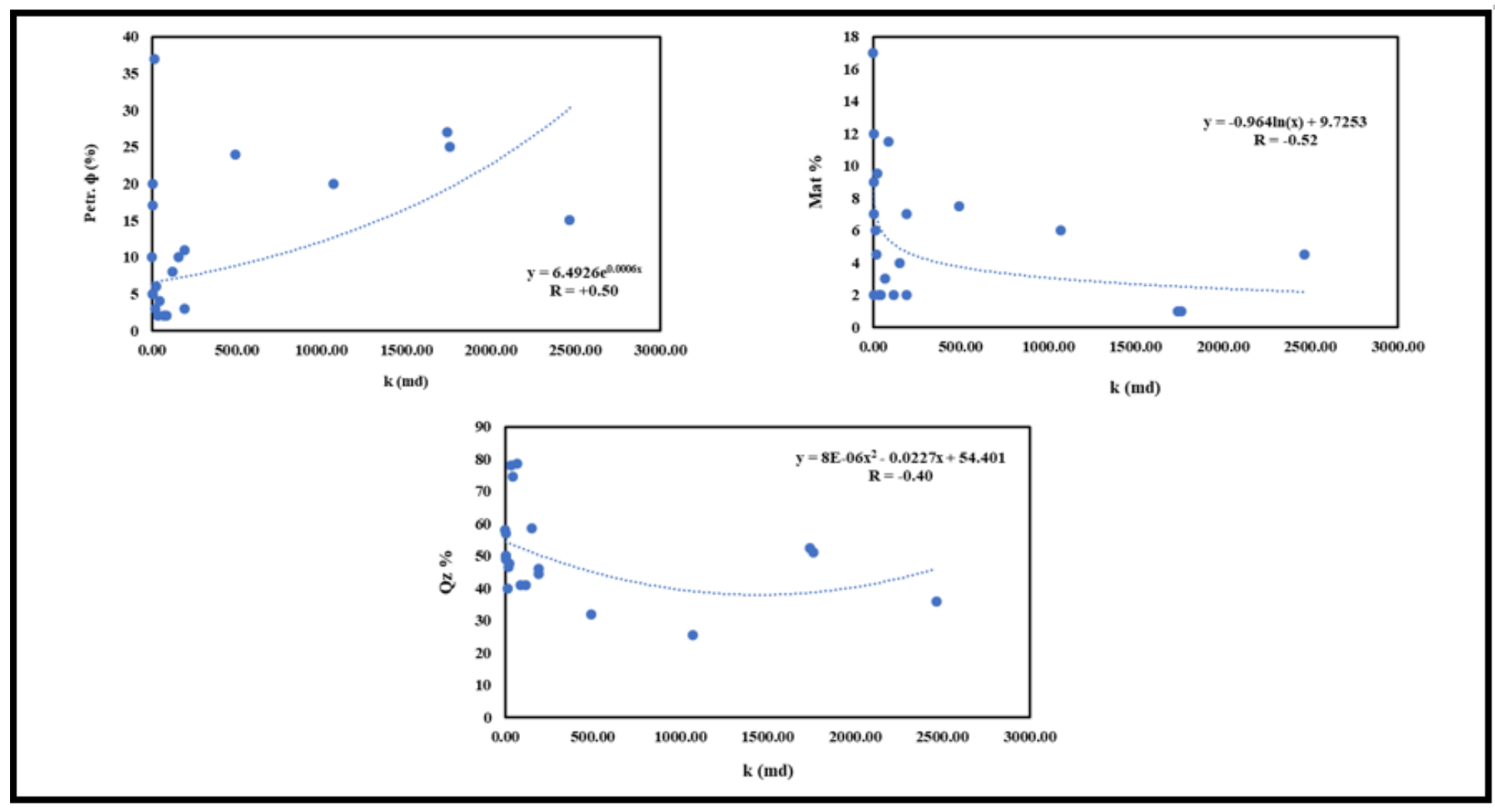

Figure 7

Bivariant relationships of some petrographic parameters with permeability of studied sandstones. 


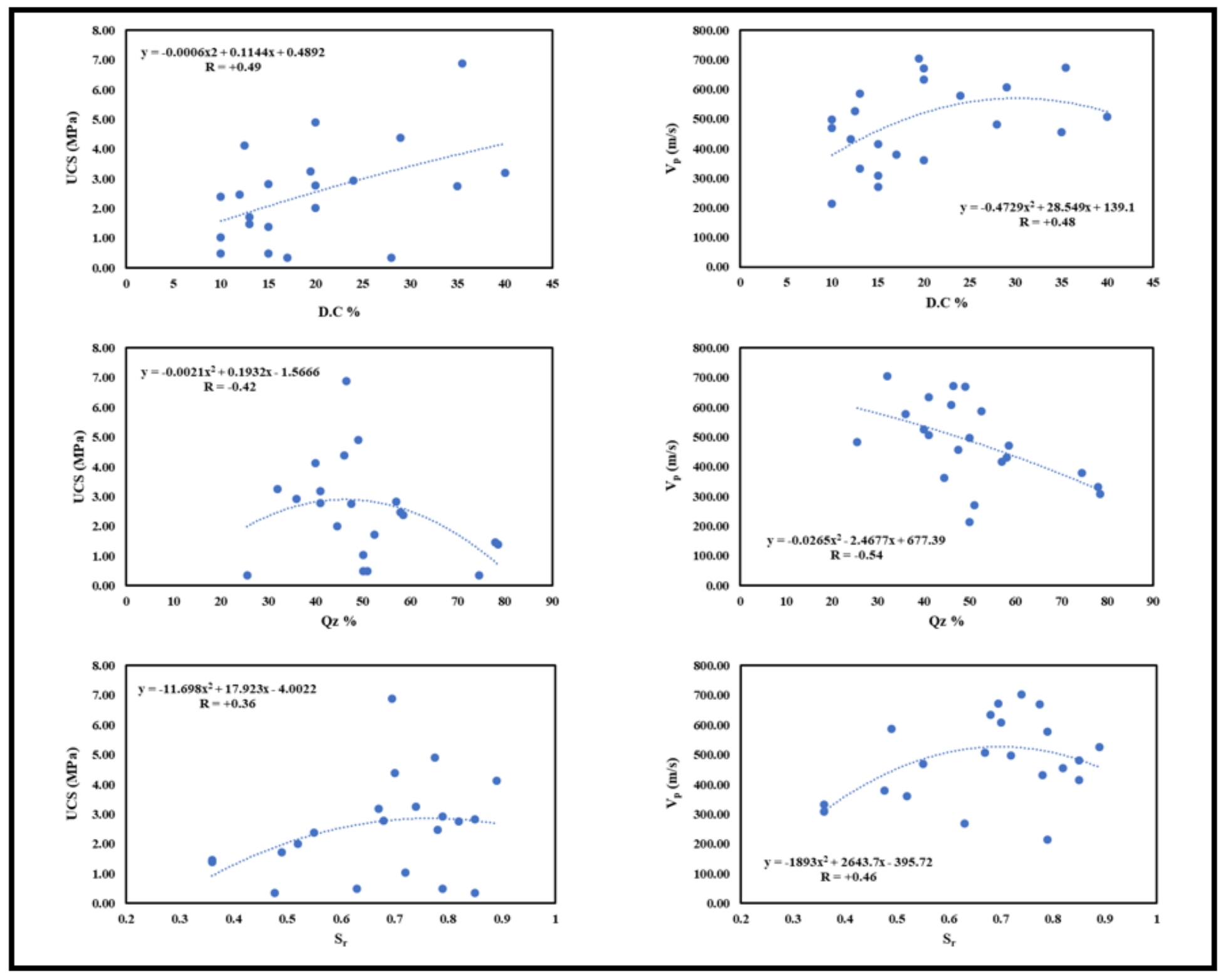

Figure 8

Bivariant relationships of some petrographic parameters with UCs and Vp properties of studied sandstones. 


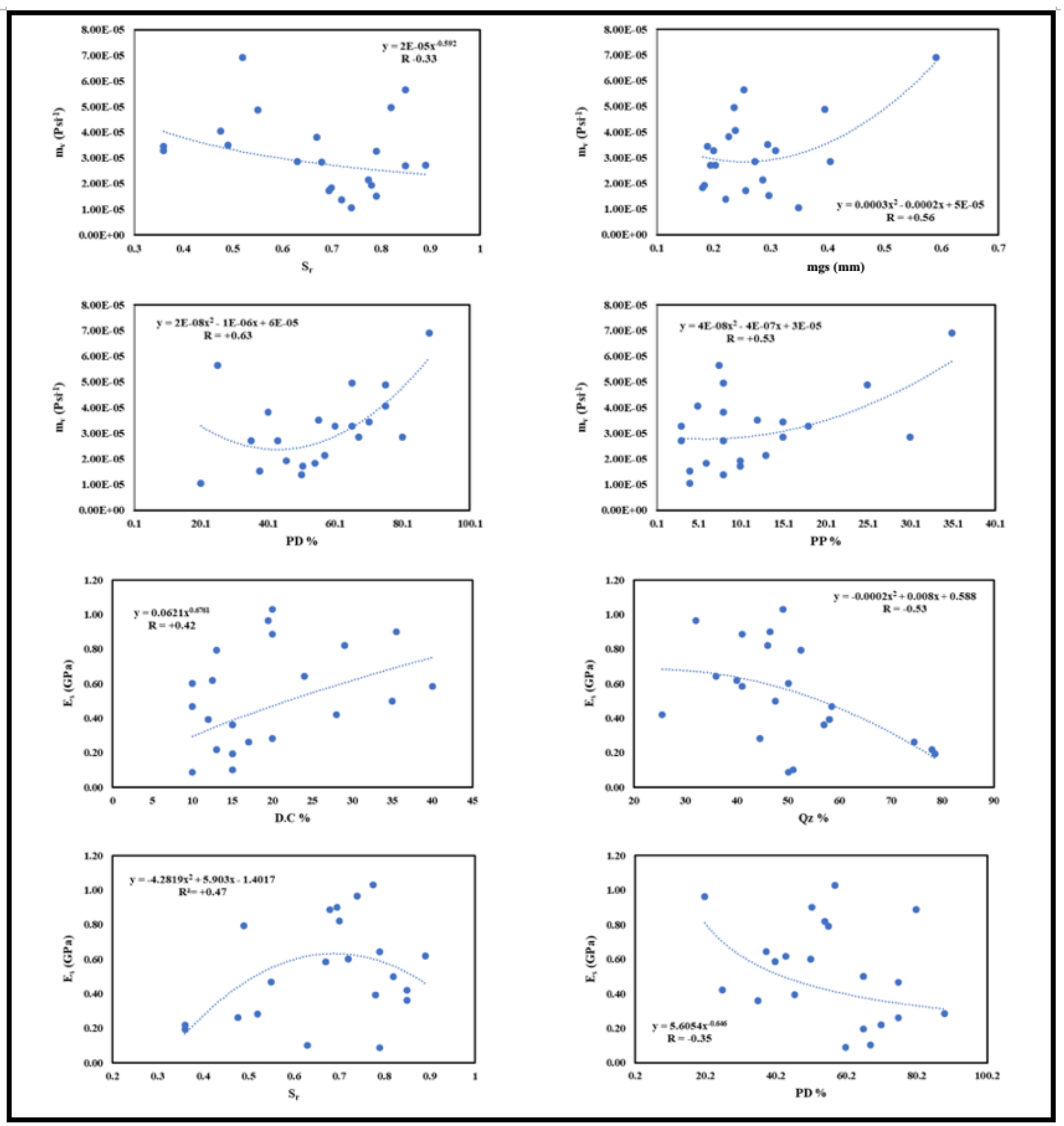

Figure 9

Bivariant relationships of some petrographic parameters with mv and Es properties of studied sandstones. 